\title{
Rainfall Variability and Its Impact on Crop Agriculture in Southwest Region of Bangladesh
}

\section{Kabir $\mathbf{H}^{1^{*}}$ and Golder $\mathrm{J}^{2}$}

${ }^{1}$ International Islamic University Malaysia, Kulliyyah of Architecture and Environment Design (KAED), Malaysia

${ }^{2}$ Department of Geography and Environment, Faculty of Earth and Environmental Sciences, University of Dhaka, Dhaka

*Corresponding author: Kabir H, International Islamic University Malaysia, Kulliyyah of Architecture and Environment Design (KAED), Malaysia, Tel: +60361964000; Email: hksmmm@gmail.com

Received date: Feb 07, 2017; Accepted date: Mar 01, 2017; Published date: Mar 07, 2017

Copyright: (c) 2017 Kabir H, et al. This is an open-access article distributed under the terms of the Creative Commons Attribution License, which permits unrestricted use, distribution, and reproduction in any medium, provided the original author and source are credited.

\begin{abstract}
The amounts of annual rainfall in the southwestern part of Bangladesh are almost equal having very little spatial variation. Significant decreasing trend (Mann-Kendal) of annual rainfall over the region is found $(-4.5 \mathrm{~mm} / \mathrm{year}$ at Mongla, $-9.14 \mathrm{~mm} / \mathrm{year}$ at Jessore, $-15.71 \mathrm{~mm} /$ year at Madaripur) except Khulna, Satkhira and Khepupara, where the trend is positive over the long period (1948-2014) but it exhibits a decreasing trend during the recent period i.e., after 1980s. It clearly indicates a gradual decrease of the amount of rainfall over southwestern part, which has become most prominent in the recent climatic period of 1981-2014. The trend is more intense at the upper southwestern part, i.e., places like Jessore and Madaripur. Annual rainfall deviates within the range $-42.6 \%$ to $+48.6 \%$ over the region. Most wide annual deviation is observed in Khulna from $48.6 \%$ to $-35.5 \%$. Like annual rainfall, seasonal rainfall also has anomalous behaviour over the region. Monsoon rainfall at maximum locations are syncline with annual trend, but at Khulna, Satkhira and Mongla though the annual trend is negative but the monsoon trend is positive, it clearly indicates, intensification of rainfall in monsoon period over the fore southwestern part. In pre-monsoon season, overall rainfall trend is significantly negative at maximum places $(-8.49 \mathrm{~mm} / \mathrm{year}$ at Jessore, $-2.02 \mathrm{~mm} /$ year at Barisal, $-7.80 \mathrm{~mm} / \mathrm{year}$ at Madaripur) over the region except Khulna, satkhira and Khepupara. But in Khulna and Satkhira it is also significantly negative over recent climatic period.
\end{abstract}

Rainfall deviation is higher in seasonal scale than the annual scale. Among the seasons wider deviation is observed in winter (from $-100.0 \%$ to $+586 \%$ ) and narrower in monsoon (from $-43.0 \%$ to $+62.1 \%$ ). The coastal region of southwest Bangladesh has been facing various natural extremes like salinity intensification, drainage congestion, inundation, water logging etc. Anomalous behavior of rainfall in combination with these problems, affecting agricultural crop production in the upazilas under study. The problem is serious in Rabi season, where groundwater irrigation facility is limited for salinity problem. In these areas agriculture is totally dependent on surface water (irrigation canal), which becomes scarce during the month of January, February, March and rainfall is also becoming low in this time (supports by public opinion and rainfall trend analysis) imposing water shortage in crop field and as a result farmers have to incur yield reduction. In monsoon season problem is different. Drainage congestion is a major problem in this time. A little heavy rainfall causes inundation and water logged condition. Besides this problem, increasing trend of rainfall in monsoon is very likely to intensify the risk of inundation. And the farmers of the study area have already faced total damage of Aus crop due to flooding in some years with comparatively high rainfall or fallow due to water logged condition. Moreover, overall decreasing trend of rainfall is more likely to intensify the risks of salinization due to decreasing upstream flow as well as sedimentation on river bed and consequent poor drainage and water logging. This intensified environmental problem is further likely to intensify the detrimental effects on crop production. So, changing pattern of rainfall in combination with the local environmental stress is being imposed on risk of agricultural crop production over the study area. It is also occasionally responsible for crop failure over the study area. It is also likely to further intensify the risk for future time.

Keywords: Southwestern; Khulna; Sathkhira; Jessore; Khepupara

\section{Introduction}

Rainfall is one of the major climatic parameters and is also a major influencing factor for crop production [1]. Crop agriculture practices of a particular region are normally dependent on the precipitation pattern of that area. But now-a-days warming of the climate system is unequivocal, and since the 1950s, many of the observed changes are unprecedented over decades to millennia [2].

IPCC estimated that changes in precipitation in a warming world will not be uniform. In many mid latitude and subtropical dry regions, mean precipitation will likely to decrease, while in many mid-latitude and tropical wet regions, mean precipitation will likely to increase. Besides, extreme precipitation events over wet tropical regions will very likely become more intense and more frequent as global mean surface temperature increases [2].

This change in precipitation, combined with increasing demand for food, would pose large risks to food security globally (high confidence). Moreover, it is projected to reduce renewable surface water and groundwater resources in most subtropical regions (robust evidence, high agreement), intensifying competition for water among ssectors. 


\section{Variability of Rainfall}

Rainfall variability is the fluctuations of rainfall occurrence annually or seasonally above or below a long term normal value. Every year, in a specific time period the rainfall of a location can be different, either above or below normal, it is the variability [2], but round the year, the mean is not different.

The severity of impact of a climatic change depends on the specific physiographic setting of a particular area, i.e., the way, how the physiography interplay with the change and also the socio-economic and cultural strength of the people living there to act with it. The physiography of the southwest coastal region of Bangladesh is almost different from rest of the landmass of the country. It is a floodplain delta, having numerous beels, peat basins, swamps, rivers and canals. Elevation of the total landmass is very low and it is within $1 \mathrm{~m}$ above mean sea level [3].

The area covers 47,201 square kilometer land area, which is $32 \%$ of total landmass of the country [4]. Water area covers 370.4 square $\mathrm{km}$ (200 nautical miles) from the coastline including estuaries and the internal river water [5]. The landmass is very young and is also growing through erosion and accession activities of major rivers. A part of the coastal area, the Sundarbans, is a mangrove forest covering about $4,500 \mathrm{~km}^{2}$, and the remaining part of the area is used for agriculture [1].

Bangladesh is considered as a one of the most disaster prone countries in the world [6]. Climate change is a major concern here. Climate change assumed to amplify existing risks and create new risks for natural and human systems.

But risks are unevenly distributed and are generally greater for disadvantaged people and communities in the country. The southwest region of Bangladesh is more vulnerable to climate change than other parts of the country due to high spatial and temporal climatic variability, extreme weather events, environmental stress, high population density, high incidence of poverty and social inequity, inadequate financial resources, and poor infrastructure [7]. So any adverse change is likely to influence tremendously the life and livelihood of people living here.
The impact of climate change on food production is of global concern, and also very important for Bangladesh. Agriculture in Bangladesh is already under pressure both from huge and increasing demands for food, and from problems of agricultural land and water resources depletion [8].

Bangladesh needs to increase the rice yield in order to meet the growing demand for food emanating from population growth. Irrigated rice or Boro is a potential area for increasing rice yield, which currently accounts for about $50 \%$ of the total rice production in the country [9]. However, change in hydrological cycle is a potential threat towards attaining this objective. It is therefore very important to understand the effect of rainfall variability on crop production NIDOS [10], in southwest coastal area to get a comprehensive knowledge on how rainfall variability is interplaying with coastal crop agriculture and its underlying risks.

Various studies have already been conducted to examine rainfall variability [11-13]. Some have also run GCM model to identify rainfall trend and to make future projections $[8,14]$. But most of these researches are either conducted over the whole country and generalizes overall feature not focusing on physiographic and environmental issues of coastal region or over a specific season or not considered the impact perceived at local level.

Some studies also conducted over southwest region focusing agriculture, climatic and hydrological problems like drought, salinity intrusion etc., $[1,6,15,16]$ but not considered the rainfall variability interplay with crop agriculture. The present study aimed to analyze rainfall variability trend and its consequent impact on crop agriculture in the environmental condition of the southwest coastal region.

A deeper understanding of the characteristics and distribution pattern of rainfall will support water management, agricultural development and disaster management planning in Bangladesh in the context of global climate change in southwest region of the country (Tables 1-4).

\begin{tabular}{|c|c|c|c|c|}
\hline Name of AEZS & Areal Coverage & $\begin{array}{l}\text { Organic Matter } \\
\text { Content }\end{array}$ & Fertility Level & Suitable Crops \\
\hline $\begin{array}{l}\text { High Ganges River } \\
\text { Floodplain }\end{array}$ & $\begin{array}{l}\text { It covers study area districts of Jessore, } \\
\text { Satkhira and Khulna together with minor } \\
\text { areas of Narail district }\end{array}$ & Low & Low & $\begin{array}{l}\text { Kharif: B. Aus, T. Aman, T. Aus, Mungbean, Jute, } \\
\text { Cotton. } \\
\text { Rabi: Wheat, Mustard, Chickpea, Lentil, Boro rice }\end{array}$ \\
\hline $\begin{array}{l}\text { Lower Ganges River } \\
\text { Floodplain }\end{array}$ & $\begin{array}{l}\text { It covers Narail, North eastern part of } \\
\text { Khulna, and Bagerhat and northern Barisal }\end{array}$ & Medium to high & Medium & $\begin{array}{l}\text { Kharif: B. Aus, B. Aman, T. Aman, Jute, Kaon, } \\
\text { GM. } \\
\text { Rabi: Pulses, Wheat, Mustard, Linseed, Boro rice }\end{array}$ \\
\hline $\begin{array}{l}\text { Ganges } \\
\text { Floodplain }\end{array}$ & $\begin{array}{l}\text { All or most of the Barisal, Jhalakathi, } \\
\text { Pirojpur, Patuakhali, Bagerhat, Khulna and } \\
\text { Satkhira districts. Ti includes the Khulna } \\
\text { and Bagerhat Sundarbans reserve forest }\end{array}$ & Medium to high & High & $\begin{array}{l}\text { Kharif: B. Aus, T. Aman, Green manures. } \\
\text { Rabi: Boro rice, Wheat, Mungbean, Grasspea, } \\
\text { Cowpea, Chili }\end{array}$ \\
\hline Gopalganj Khulna Beels & $\begin{array}{l}\text { A number of separate basin areas in } \\
\text { Madaripur, Gopalganj, Narail, Jessore, } \\
\text { Bagerhat and Khulna districts }\end{array}$ & Medium to high & Medium & $\begin{array}{l}\text { Kharif: T. Aman, T. Aus, Jute, Sesame, B. Aman. } \\
\text { Rabi: Boro rice, Bean, Wheat, Grasspea }\end{array}$ \\
\hline
\end{tabular}

Table 1: Agro-ecological zones lied in the study area. 
Citation: Kabir H, Golder J (2017) Rainfall Variability and Its Impact on Crop Agriculture in Southwest Region of Bangladesh. J Climatol Weather

Page 3 of 20

\begin{tabular}{|l|l|l|l|l|}
\hline Station & Lat./Long. & $\begin{array}{l}\text { Area } \\
\text { Category }\end{array}$ & $\begin{array}{l}\text { Period of } \\
\text { Record }\end{array}$ & $\begin{array}{l}\text { Record } \\
\text { Length }\end{array}$ \\
\hline Jessore & $23.17^{\circ} \mathrm{N} 89.22^{\circ} \mathrm{E}$ & $\mathrm{ICZ}$ & $1948-2014$ & 67 \\
\hline Satkhira & $22.68^{\circ} \mathrm{N} 89.07^{\circ} \mathrm{E}$ & $\mathrm{ICZ}$ & $1948-2014$ & 67 \\
\hline Khulna & $22.80^{\circ} \mathrm{N} 89.58^{\circ} \mathrm{E}$ & $\mathrm{ICZ}$ & $1948-2014$ & 67 \\
\hline Madaripur & $23.16^{\circ} \mathrm{N} 90.18^{\circ} \mathrm{E}$ & $\mathrm{NCZ}$ & $1977-2014$ & 38 \\
\hline Mongla & $22.46^{\circ} \mathrm{N} 89.6^{\circ} \mathrm{E}$ & $\mathrm{ECZ}$ & $1991-2014$ & 24 \\
\hline Barisal & $22.70^{\circ} \mathrm{N} 90.36^{\circ} \mathrm{E}$ & $\mathrm{ICZ}$ & $1949-2014$ & 66 \\
\hline Patuakhali & $22.36^{\circ} \mathrm{N} 90.34^{\circ} \mathrm{E}$ & $\mathrm{ECZ}$ & $1973-2014$ & 42 \\
\hline Khepupara & $21.98^{\circ} \mathrm{N} 90.22^{\circ} \mathrm{E}$ & $\mathrm{ECZ}$ & $1974-2014$ & 41 \\
\hline $\begin{array}{l}\text { ICZ: Interior } \text { Coastal Zone; ECZ: Exposed Coastal Zone; NCZ: Non Coastal } \\
\text { Zone }\end{array}$ & & & \\
\hline
\end{tabular}

Table 2: Location of rainfall records of BMD weather stations under study.

\begin{tabular}{|c|c|c|c|c|}
\hline Station & Lat./Long. & Area Category & $\begin{array}{l}\text { Period of } \\
\text { Record }\end{array}$ & $\begin{array}{l}\text { Record } \\
\text { Length }\end{array}$ \\
\hline Jessore & $\begin{array}{l}23.17^{\circ} \mathrm{N} \\
89.20^{\circ} \mathrm{E}\end{array}$ & $\mathrm{ICZ}$ & $1998-2014$ & 17 \\
\hline Narail & $\begin{array}{l}23.13^{\circ} \mathrm{N} \\
89.50^{\circ} \mathrm{E}\end{array}$ & ICZ & $1998-2014$ & 17 \\
\hline Gopalganj & $\begin{array}{l}23.20^{\circ} \mathrm{N} \\
89.80^{\circ} \mathrm{E}\end{array}$ & $\mathrm{ICZ}$ & $1998-2014$ & 17 \\
\hline Madaripur & $\begin{array}{l}23.17^{\circ} \mathrm{N} \\
90.10^{\circ} \mathrm{E}\end{array}$ & $\mathrm{NCZ}$ & 1998-2014 & 17 \\
\hline Satkhira & $\begin{array}{l}22.35^{\circ} \mathrm{N} \\
89.08^{\circ} \mathrm{E}\end{array}$ & $\mathrm{ICZ}$ & $1998-2014$ & 17 \\
\hline Khulna & $\begin{array}{l}22.35^{\circ} \mathrm{N} \\
89.30^{\circ} \mathrm{E}\end{array}$ & $\mathrm{ICZ}$ & $1998-2014$ & 17 \\
\hline Bagerhat & $\begin{array}{l}22.06^{\circ} \mathrm{N} \\
89.08^{\circ} \mathrm{E}\end{array}$ & $\mathrm{ICZ}$ & $1998-2014$ & 17 \\
\hline Barisal & $\begin{array}{l}22.80^{\circ} \mathrm{N} \\
90.37^{\circ} \mathrm{E}\end{array}$ & $\mathrm{ICZ}$ & $1998-2014$ & 17 \\
\hline Jhalakathi & $\begin{array}{l}22.6431^{\circ} \mathrm{N} \\
90.20^{\circ} \mathrm{E}\end{array}$ & ICZ & 1998-2014 & 17 \\
\hline Pirojpur & $\begin{array}{l}22.58^{\circ} \mathrm{N} \\
89.97^{\circ} \mathrm{E}\end{array}$ & ICZ & 1998-2014 & 17 \\
\hline Patuakhali & $\begin{array}{l}22.354^{\circ} \mathrm{N} \\
90.3181^{\circ} \mathrm{E}\end{array}$ & ECZ & 1998-2014 & 17 \\
\hline Barguna & $\begin{array}{l}22.1508^{\circ} \mathrm{N} \\
90.1264^{\circ} \mathrm{E}\end{array}$ & ECZ & $1998-2014$ & 17 \\
\hline Koyra & $\begin{array}{l}22.20^{\circ} \mathrm{N} \\
89.40^{\circ} \mathrm{E}\end{array}$ & $E C Z$ & $1998-2014$ & 17 \\
\hline Karamjol & $\begin{array}{l}22.43^{\circ} \mathrm{N} \\
89.6^{\circ} \mathrm{E}\end{array}$ & $\mathrm{ECZ}$ & 1998-2014 & 17 \\
\hline
\end{tabular}

\begin{tabular}{|l|l|l|l|l|}
\hline Pashurtala & $\begin{array}{l}22.244^{\circ} \mathrm{N} \\
89.443^{\circ} \mathrm{E}\end{array}$ & $\mathrm{ECZ}$ & $1998-2014$ & 17 \\
\hline Arpangachia & $\begin{array}{l}22.313^{\circ} \mathrm{N} \\
89.461^{\circ} \mathrm{E}\end{array}$ & $\mathrm{ECZ}$ & $1998-2014$ & 17 \\
\hline Sibsa Point & $\begin{array}{l}21.983^{\circ} \mathrm{N} \\
89.533^{\circ} \mathrm{E}\end{array}$ & $\mathrm{ECZ}$ & $1998-2014$ & 17 \\
\hline Supati & $\begin{array}{l}22.057^{\circ} \mathrm{N} \\
89.818^{\circ} \mathrm{E}\end{array}$ & $\mathrm{ECZ}$ & $1998-2014$ & 17 \\
\hline
\end{tabular}

Table 3: Selected locations of TRMM rainfall records under study.

\section{Rainfall Variability over Southwestern Part of Bangladesh}

The observed annual rainfall over southwestern part of Bangladesh varies from location to location. It is the lowest of $1607.8 \mathrm{~mm}$ (at Satkhira) and the highest of $2608.7 \mathrm{~mm}$ (at Patuakhali). The standard deviation of annual rainfall over this region varies from 334.0 to 586.3 $\mathrm{mm}$. The mean annual rainfall of each of the location under study and their standard deviations are given in Figure 1. TRMM rainfall at each of district headquarters as well as some selected locations of southwestern part of Bangladesh exhibits almost similar scenario. From TRMM data it is found that the mean annual rainfall varies between from 1680.3 to $2467.3 \mathrm{~mm}$ during the study period of 1998-2014.

The highest amount of rainfall is observed at Patuakhali but the lowest is at Jessore. The mean annual rainfall was higher over the eastern part and lower over western part of the region. The standard deviation of rainfall was maximum at Supati but it is lowest at Jessore. Long periodic (1948-2014) annual rainfall of the Jessore, Satkhira, Khulna and Barisal indicates that the rainfall variability is high at these locations as it is found for the recent climate period (1981-2014). Accordingly, the mean rainfall for long period over Jessore, Satkhira, Khulna and Barisal are 2157.2, 1705.3, 1751.9 and $2115.6 \mathrm{~mm}$ respectively and their STDs are 457.4, 308.8, 368.1 and $426.0 \mathrm{~mm}$ respectively.

The mean and STDs of the rainfall of long and short period of these stations fluctuates slightly that is the indication of the similar annual rainfall variability over this region (Figure 2 ).

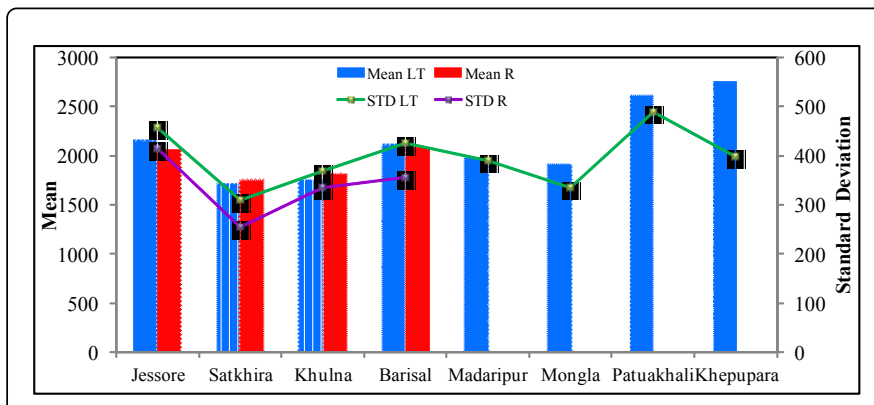

Figure 1: Mean annual rainfall with corresponding STD at different weather stations of BMD. 
Citation: Kabir H, Golder J (2017) Rainfall Variability and Its Impact on Crop Agriculture in Southwest Region of Bangladesh. J Climatol Weather

\begin{tabular}{|c|c|c|c|c|c|c|c|}
\hline \multirow{2}{*}{ Description } & \multirow{2}{*}{$\begin{array}{l}\text { Total cultivable } \\
\text { area (ha) }\end{array}$} & \multirow{2}{*}{ Saline Area } & \multicolumn{5}{|c|}{$\begin{array}{l}\text { Area of each salinity class } \\
(d S / m)\end{array}$} \\
\hline & & & $\begin{array}{l}\text { S1 } \\
(2.0-4.0)\end{array}$ & $\begin{array}{l}\text { S2 } \\
(4.1-8.0)\end{array}$ & $\begin{array}{l}\text { S3 } \\
(8.1-12.0)\end{array}$ & $\begin{array}{l}\text { S4 } \\
(12.1-16.0)\end{array}$ & $\begin{array}{l}\text { S5 } \\
(>16.0)\end{array}$ \\
\hline $\begin{array}{l}\text { Non-saline with very } \\
\text { slightly saline }\end{array}$ & $4,25,490$ & $\begin{array}{l}1,15,370 \\
(27 \%)\end{array}$ & $\begin{array}{l}82,260 \\
(72 \%)\end{array}$ & $\begin{array}{l}31,590 \\
(27 \%)\end{array}$ & $\begin{array}{l}1,520 \\
(1 \%)\end{array}$ & 0 & 0 \\
\hline $\begin{array}{l}\text { Very slightly saline with } \\
\text { slightly saline }\end{array}$ & $4,20,420$ & $\begin{array}{l}3,09,190 \\
(73 \%)\end{array}$ & $\begin{array}{l}1,70,380 \\
(55 \%)\end{array}$ & $\begin{array}{l}1,10,390 \\
(35 \%)\end{array}$ & $\begin{array}{l}29,420 \\
(10 \%)\end{array}$ & 0 & 0 \\
\hline $\begin{array}{l}\text { Slightly saline with } \\
\text { moderately saline }\end{array}$ & $2,57,270$ & $\begin{array}{l}2,40,220 \\
(93 \%)\end{array}$ & $\begin{array}{l}35,490 \\
(15 \%)\end{array}$ & $\begin{array}{l}1,13,890 \\
(47 \%)\end{array}$ & $\begin{array}{l}61,240 \\
(26 \%)\end{array}$ & $\begin{array}{l}25,870 \\
(11 \%)\end{array}$ & $\begin{array}{l}2,650 \\
(1 \%)\end{array}$ \\
\hline $\begin{array}{l}\text { Moderately saline with } \\
\text { strongly saline }\end{array}$ & $1,98,890$ & $\begin{array}{l}1,98,890 \\
(100 \%)\end{array}$ & $\begin{array}{l}1,630 \\
(1 \%)\end{array}$ & $\begin{array}{l}36,060 \\
(18 \%)\end{array}$ & $\begin{array}{l}73,400 \\
(37 \%)\end{array}$ & $\begin{array}{l}55,130 \\
(28 \%)\end{array}$ & $\begin{array}{l}32,750 \\
(16 \%)\end{array}$ \\
\hline
\end{tabular}

Table 4: Salinity affected areas in the coastal regions of Bangladesh.

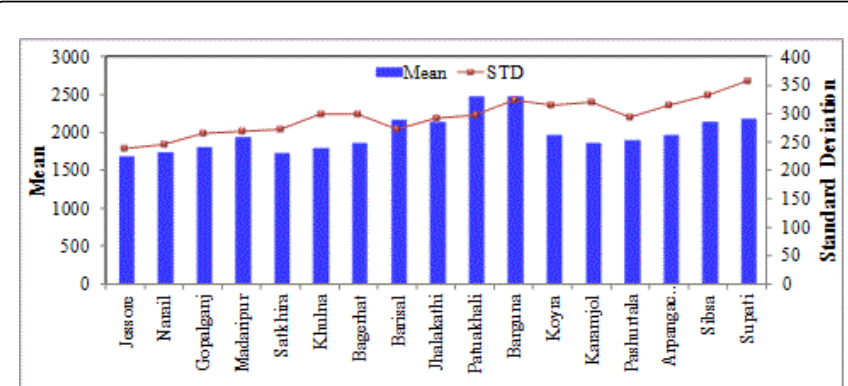

Figure 2: Mean annual rainfall with corresponding STD of TRMM rainfall in different locations of SW region of Bangladesh.

Analysis also reveals that the higher amounts of rainfall are recorded in the monsoon months with the maximum in July followed by June or August (Figure 3). Accordingly, about 69.1, 71.3, 70.9, 69.8,
$67.8,71.9,74.0$ and $72.9 \%$ rainfall are recorded in monsoon, about $23.0,15.3,17.1,16.9,21.3,15.0,15.4$ and $14.5 \%$ in pre-monsoon, about 9.6, 9.7, 9.5, 10.6, 9.6, 11.1, 9.6 and $11.5 \%$ in post-monsoon and about $1.7,3.8,2.2,1.7,1.8,2.0,1.3$ and $1.3 \%$ in Patuakhali and Khepupara. The mean monthly, seasonal and annual rainfall and their STDs of the stations are under study is given in Figures 1, 3 and 4 and in Tables 5 and 6. Winter season respectively in Jessore, Satkhira, Khulna, Barisal, Madaripur, Mongla, Mean seasonal rainfall is highest in Monsoon and lowest in winter. Long term mean monsoon rainfall varies between $1228.6 \mathrm{~mm}$ to $2001.4 \mathrm{~mm}$ (Figure 4). Highest value was observed in Khepupara and lowest at Satkhira. It deviates within the range 135.0 $\mathrm{mm}$ to $388.3 \mathrm{~mm}$ (Table 1). Mean Pre-monsoon rainfall was found within $271.0 \mathrm{~mm}$ (Satkhira) to $519.5 \mathrm{~mm}$ (Jessore) range. Mean Postmonsoon rainfall was within $165.8 \mathrm{~mm}$ (Khulna) to $314.9 \mathrm{~mm}$ (Khepupara). Mean winter rainfall was observed within a very short range of $34.0 \mathrm{~mm}$ (Madaripur) to $50.4 \mathrm{~mm}$ (Khulna). In most of the cases STD value becomes lower in recent climatic period reveals decline of in fluctuation in rainfall amount (Figure 4).
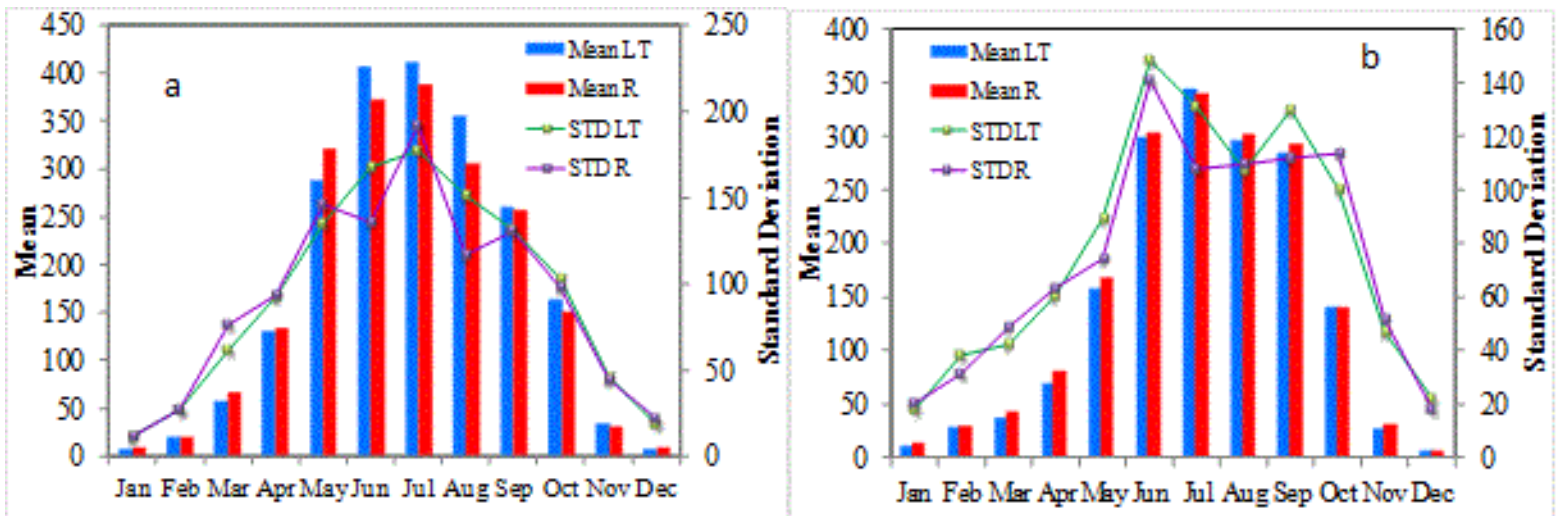

Figure 3: Mean monthly rainfall with corresponding STD at (a) Jessore, (b) Satkhira weather stations of BMD. 
Citation: Kabir H, Golder J (2017) Rainfall Variability and Its Impact on Crop Agriculture in Southwest Region of Bangladesh. J Climatol Weather Forecasting 5: 196. doi:10.4172/2332-2594.1000196

Page 5 of 20
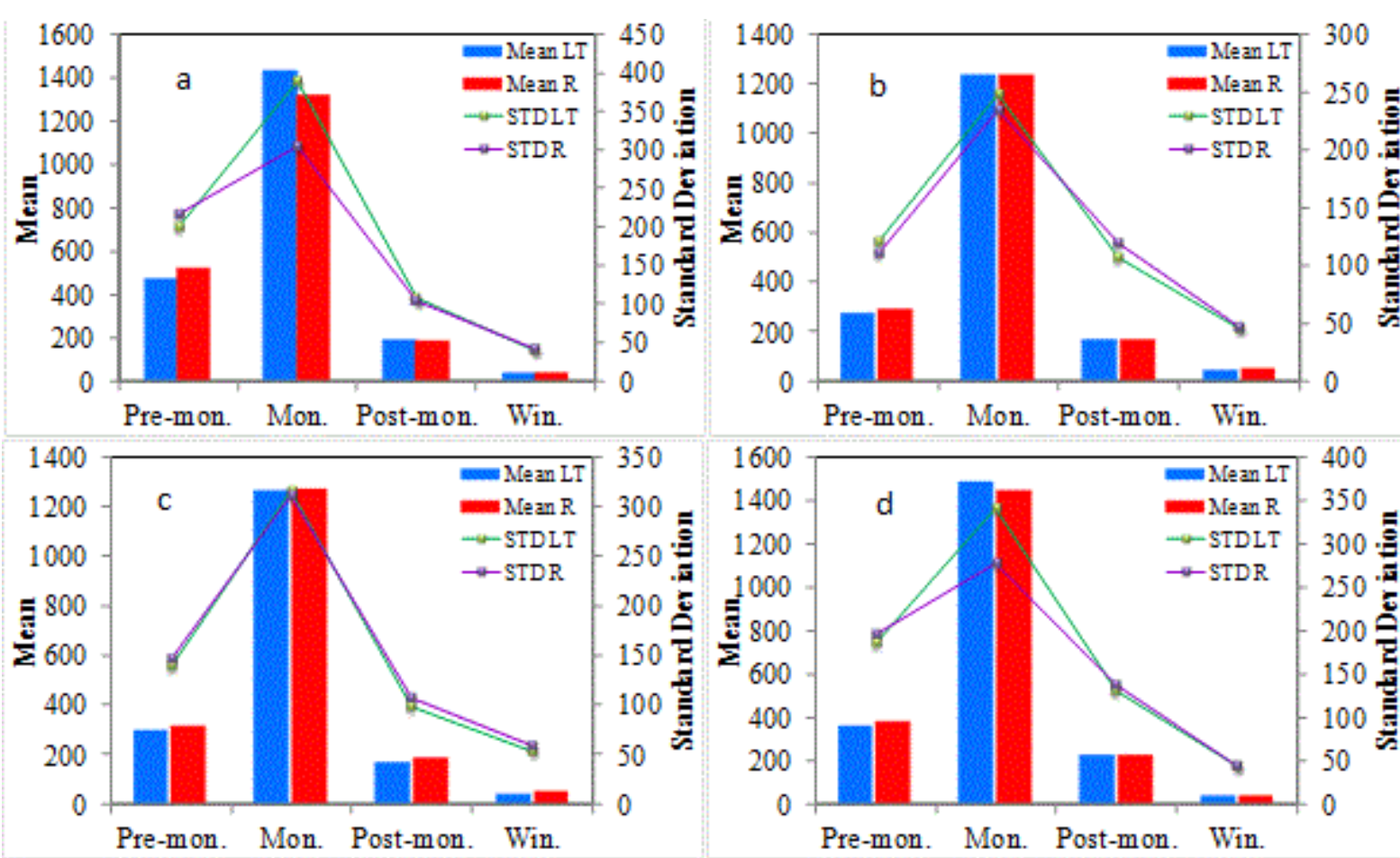

Pre-mon. Mon. Post-mon. Win.
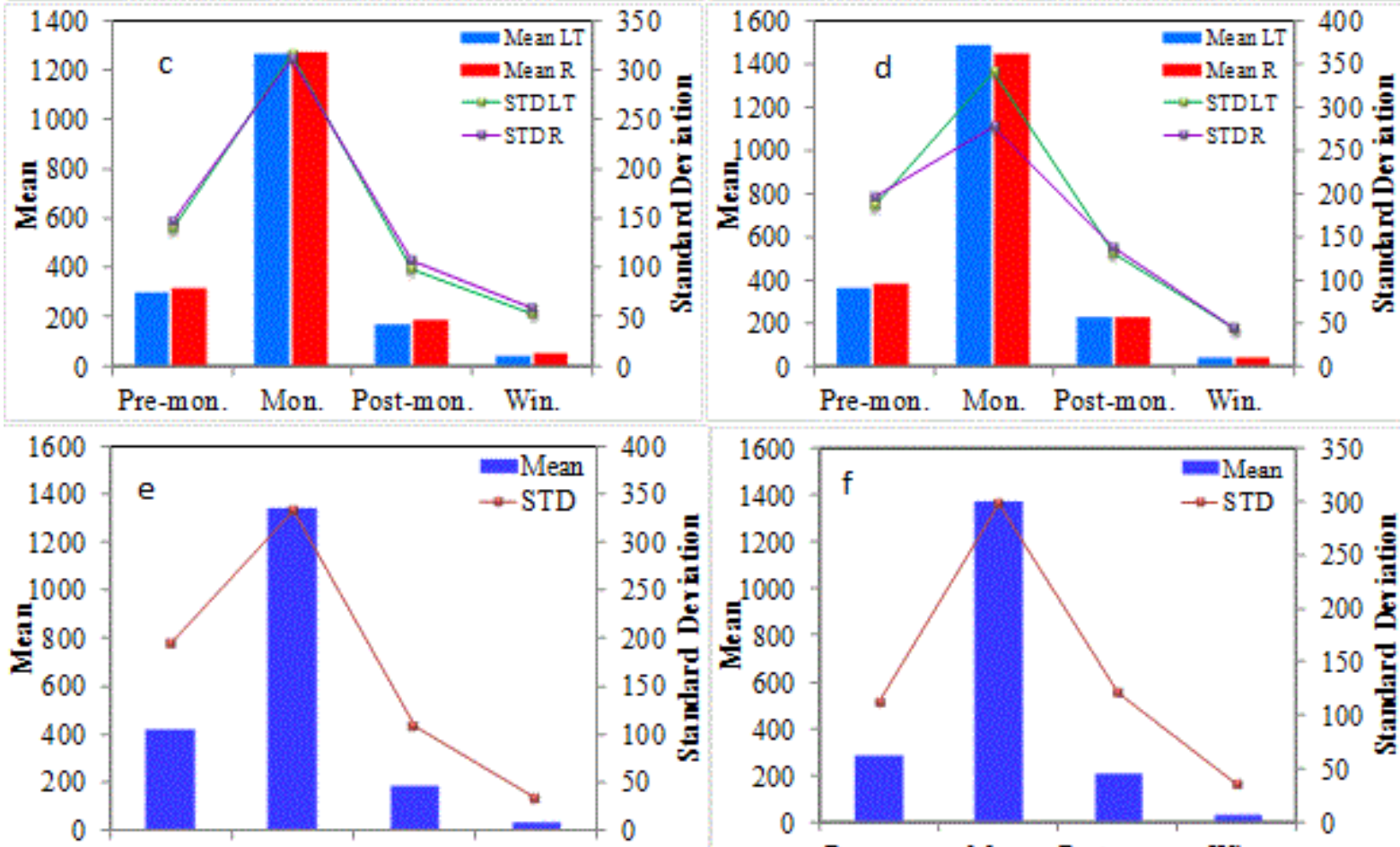

Pre-mon. Mon. Post-mon. Win.
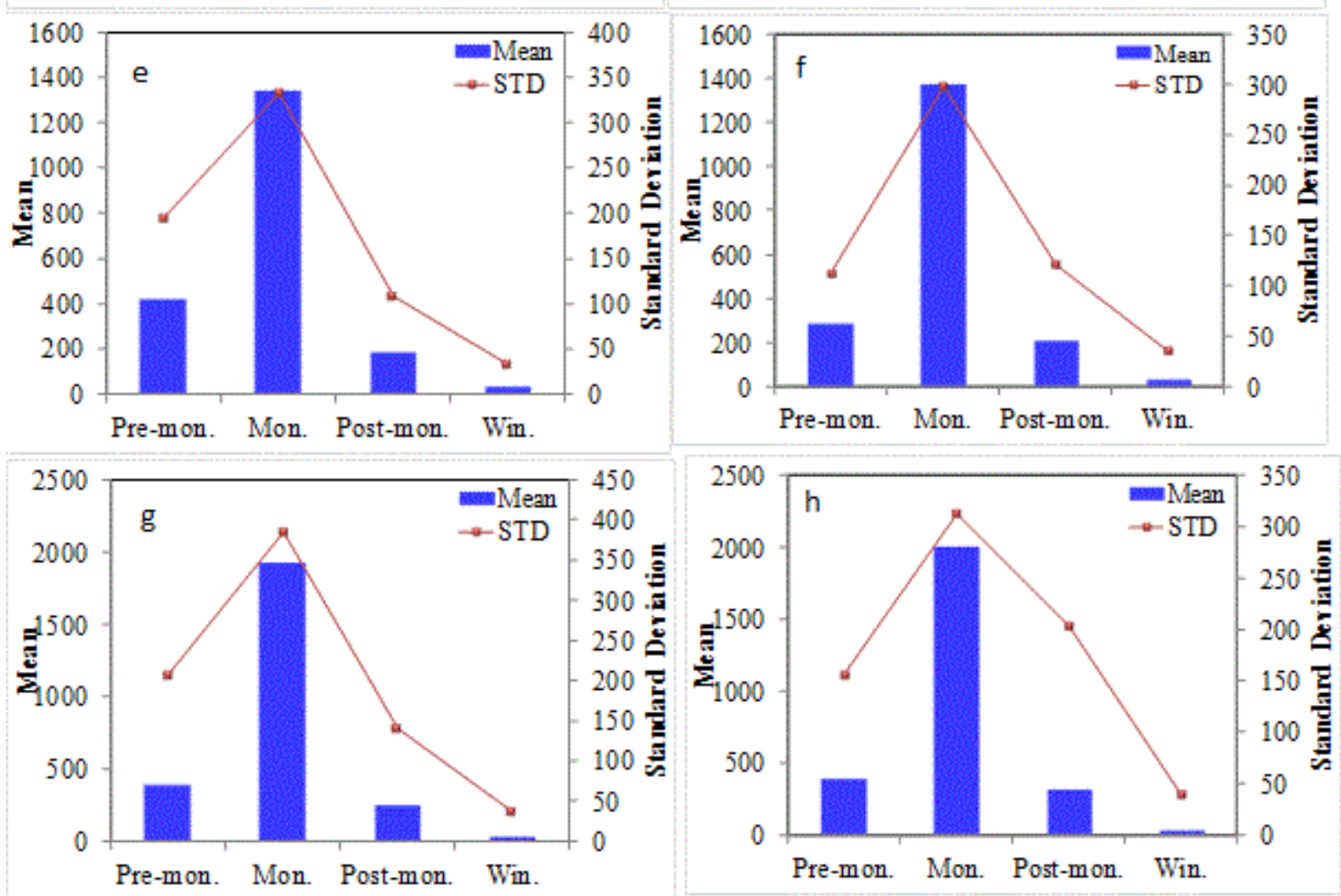

Figure 4: Mean seasonal rainfall with corresponding STD at (a) Jessore, (b) Satkhira, (c) Khulna, (d) Barisal, (e) Madaripur, (f) Mongla, (g) Patuakhali and (h) Khepupara weather stations of BMD. 
Citation: Kabir H, Golder J (2017) Rainfall Variability and Its Impact on Crop Agriculture in Southwest Region of Bangladesh. J Climatol Weather Forecasting 5: 196. doi:10.4172/2332-2594.1000196

Page 6 of 20

\begin{tabular}{|c|c|c|c|c|c|c|c|c|c|}
\hline \multicolumn{2}{|c|}{ Time Period } & \multirow{2}{*}{$\begin{array}{l}\text { Jessore } \\
7.7\end{array}$} & \multirow{2}{*}{$\begin{array}{l}\text { Satkhira } \\
10.6\end{array}$} & \multirow{2}{*}{$\begin{array}{l}\text { Khulna } \\
11\end{array}$} & \multirow{2}{*}{$\begin{array}{l}\text { Barisal } \\
9.5\end{array}$} & \multirow{3}{*}{$\begin{array}{l}\begin{array}{l}\text { Madaripur } \\
(1977-2014)\end{array} \\
8\end{array}$} & \multirow{3}{*}{$\begin{array}{l}\begin{array}{l}\text { Mongla } \\
(1991-2014)\end{array} \\
12.8\end{array}$} & \multirow{3}{*}{$\begin{array}{l}\begin{array}{l}\text { Patuakhali } \\
\text { (1973-2014) }\end{array} \\
7.7\end{array}$} & \multirow{3}{*}{$\begin{array}{l}\text { Khepupara } \\
(1974-2014)\end{array}$} \\
\hline \multirow{2}{*}{ Jan } & $1948-14$ & & & & & & & & \\
\hline & $1981-14$ & 8.4 & 14 & 14.9 & 10.8 & & & & \\
\hline \multirow{2}{*}{ Feb } & $1948-14$ & 20 & 27.6 & 23.5 & 19.3 & \multirow{2}{*}{23.1} & \multirow{2}{*}{22.8} & \multirow{2}{*}{21.2} & \multirow{2}{*}{20.4} \\
\hline & $1981-14$ & 19.6 & 29 & 30.2 & 20.9 & & & & \\
\hline \multirow{2}{*}{ Mar } & $1948-14$ & 57.2 & 36.2 & 42.9 & 49.9 & \multirow{2}{*}{49.7} & \multirow{2}{*}{41.5} & \multirow{2}{*}{37.5} & \multirow{2}{*}{43.1} \\
\hline & $1981-14$ & 66.6 & 42.4 & 49 & 55.1 & & & & \\
\hline \multirow{2}{*}{ Apr } & $1948-14$ & 130.4 & 68.2 & 74.8 & 94.2 & \multirow{2}{*}{120.9} & \multirow{2}{*}{54.7} & \multirow{2}{*}{100.9} & \multirow{2}{*}{88.3} \\
\hline & $1981-14$ & 133.5 & 79.6 & 75.4 & 103.2 & & & & \\
\hline \multirow{2}{*}{ May } & $1948-14$ & 286.3 & 156.2 & 181.4 & 213.5 & \multirow{2}{*}{148.2} & 1909 & 2622 & 2658 \\
\hline & $1981-14$ & 319.3 & 167.3 & 188.1 & 217 & & & & \\
\hline & $1948-14$ & 404.4 & 297.3 & 335.5 & 409.5 & & & & \\
\hline 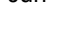 & $1981-14$ & 371.3 & 302.1 & 330.5 & 397.9 & - & $0+0.1$ & (30.0 & (300.0 \\
\hline & $1948-14$ & 409 & 342.6 & 351 & 412.8 & & & & \\
\hline & $1981-14$ & 386.4 & 337.4 & 336.8 & 408 & er... & 年 & . & \\
\hline & $1948-14$ & 353 & 293.6 & 291.3 & 353.5 & & & & \\
\hline Ruy & $1981-14$ & 303.3 & 299.9 & 315.1 & 350.3 & S10.0 & 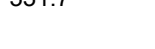 & 400.0 & 401.2 \\
\hline & $1948-14$ & 258.4 & 282 & 264.4 & 300.6 & & & & \\
\hline SEP & $1981-14$ & 255.9 & 291 & 287.5 & 281.5 & 209.1 & $3<0$ & 382.2 & 385.8 \\
\hline & $1948-14$ & 162.6 & 139.7 & 138.4 & 187.4 & & & & \\
\hline . & $1981-14$ & 150.6 & 139 & 147.2 & 186 & 158.1 & $1 / 3.1$ & 200.2 & $\angle 63.6$ \\
\hline Nov & $1948-14$ & 34.1 & 26.4 & 27.2 & 37.5 & 30.3 & 36 & 514 & 51.3 \\
\hline & $1981-14$ & 31.1 & 30.5 & 35 & 43.5 & & & & \\
\hline Dec & $1948-14$ & 6.9 & 6.6 & 3.7 & 8 & 41 & 27 & 5 & 66 \\
\hline . & $1981-14$ & 8.8 & 6.6 & 5.8 & 6.4 & 4.1 & 2.1 & 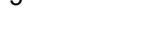 & 0.0 \\
\hline$\Gamma^{-1}$ & $1948-14$ & 474.1 & 271 & 297.8 & 359.6 & 7107 & 0071 & Pח & \\
\hline & $1981-14$ & 519.5 & 289.2 & 312.4 & 375.3 & 47.1 & 201.1 & - & 001.2 \\
\hline & $1948-14$ & 1428.5 & 1228.6 & 1262.5 & 1479.2 & ? & ? & 1020 & 0001 \\
\hline Mon. & $1981-14$ & 1311.2 & 1230.3 & 1268 & 1437.7 & 1339.3 & $13 / 2.2$ & 1922.8 & 2001.4 \\
\hline & $1948-14$ & 192.6 & 166.4 & 165.8 & 224.8 & & & & \\
\hline 1006. & $1981-14$ & 181.7 & 169.6 & 182.2 & 221.4 & 109 & 211.2 & 201.0 & 314.9 \\
\hline & $1948-14$ & 35.4 & 42.6 & 38.3 & 37.9 & & & & \\
\hline . & $1981-14$ & 36.9 & 49 & 50.4 & 37.2 & 34 & (3.0. & 34.4 & 36.2 \\
\hline & $1948-14$ & 2157.2 & 1705.3 & 1751.9 & 2115.6 & & & & \\
\hline กาा & $1981-14$ & 2053.2 & 1738.7 & 1805.4 & 2072.5 & 1000.0 & 1000.0 & 2001.0 & 2170.2 \\
\hline
\end{tabular}

Table 5: Mean monthly, seasonal and annual rainfall at different BMD weather station. 
Citation: Kabir H, Golder J (2017) Rainfall Variability and Its Impact on Crop Agriculture in Southwest Region of Bangladesh. J Climatol Weather Forecasting 5: 196. doi:10.4172/2332-2594.1000196

Page 7 of 20

\begin{tabular}{|c|c|c|c|c|c|c|c|c|c|}
\hline \multicolumn{2}{|c|}{ Time Period } & \multirow{2}{*}{$\begin{array}{l}\text { Jessore } \\
11.5\end{array}$} & \multirow{2}{*}{$\begin{array}{l}\text { Satkhira } \\
17.5\end{array}$} & \multirow{2}{*}{$\begin{array}{l}\text { Khulna } \\
20.9\end{array}$} & \multirow{2}{*}{$\begin{array}{l}\text { Barisal } \\
21.4\end{array}$} & \multirow{3}{*}{$\begin{array}{l}\begin{array}{l}\text { Madaripur } \\
(1977-2014)\end{array} \\
14.9\end{array}$} & \multirow{3}{*}{$\begin{array}{l}\begin{array}{l}\text { Mongla } \\
(1991-2014)\end{array} \\
16.5\end{array}$} & \multirow{3}{*}{$\begin{array}{l}\begin{array}{l}\text { Patuakhali } \\
(1973-2014)\end{array} \\
13.6\end{array}$} & \multirow{3}{*}{ 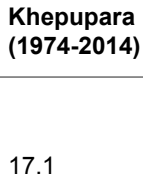 } \\
\hline & $1948-14$ & & & & & & & & \\
\hline Jan & $1981-14$ & 11.3 & 20.2 & 22.6 & 22.4 & & & & \\
\hline \multirow[b]{2}{*}{ Feb } & $1948-14$ & 26.6 & 37.8 & 40.4 & 25 & \multirow[b]{2}{*}{24} & \multirow[b]{2}{*}{27.8} & \multirow[b]{2}{*}{30.4} & \multirow[b]{2}{*}{31} \\
\hline & $1981-14$ & 26.6 & 31.3 & 42 & 26.4 & & & & \\
\hline \multirow[b]{2}{*}{ Mar } & $1948-14$ & 61.7 & 41.8 & 62 & 66.5 & \multirow[b]{2}{*}{57.7} & \multirow[b]{2}{*}{60.9} & \multirow[b]{2}{*}{57} & \multirow[b]{2}{*}{71.2} \\
\hline & $1981-14$ & 76.2 & 48.5 & 70.1 & 73.3 & & & & \\
\hline \multirow[b]{2}{*}{ Apr } & $1948-14$ & 92.8 & 60.3 & 70.9 & 79 & \multirow[b]{2}{*}{95.3} & \multirow[b]{2}{*}{44.3} & \multirow[b]{2}{*}{91.6} & \multirow[b]{2}{*}{71.1} \\
\hline & $1981-14$ & 93.1 & 63.1 & 66.1 & 83.3 & & & & \\
\hline \multirow[b]{2}{*}{ May } & $1948-14$ & 134.5 & 88.9 & 87.9 & 124.6 & \multirow[b]{2}{*}{141.1} & \multirow[b]{2}{*}{84.2} & & \\
\hline & $1981-14$ & 145.9 & 74.1 & 83.8 & 125.2 & & & 175.3 & 142.7 \\
\hline & 1948-14 & 167.5 & 148.4 & 149.4 & 180 & & & & \\
\hline Jun & $1981-14$ & 135.6 & 140.6 & 165.5 & 188.7 & 170.9 & 159.3 & 266.6 & 201.4 \\
\hline & $1948-14$ & 177.2 & 130.6 & 138 & 136 & & & & \\
\hline Jul & $1981-14$ & 192.1 & 107.4 & 108.6 & 122.8 & 127.8 & 99.7 & 155.9 & 189.8 \\
\hline & $1948-14$ & 151.2 & 107 & 130 & 143.1 & & & & \\
\hline Aug & $1981-14$ & 117.1 & 109 & 124.7 & 133.6 & 132 & 111.3 & 171.1 & 182.9 \\
\hline & 1948-14 & 131.1 & 129.6 & 157.4 & 167.9 & & & & \\
\hline Sep & $1981-14$ & 130.6 & 111.4 & 161.8 & 169.2 & 149.9 & 134 & 179.4 & 161.7 \\
\hline & $1948-14$ & 130 & 99.8 & 92 & 117.7 & & & & \\
\hline Oct & $1981-14$ & 98 & 113.3 & 104.1 & 127.4 & 103.8 & 105.2 & 129.5 & 175.2 \\
\hline & $1948-14$ & 46.4 & 46.6 & 47.8 & 58.4 & & & & \\
\hline Nov & $1981-14$ & 44.4 & 51.5 & 54.7 & 69.5 & 42.2 & 63.8 & 71.4 & 96.3 \\
\hline & 1948-14 & 18.5 & 21.6 & 10.8 & 26 & & & & \\
\hline Dec & $1981-14$ & 21.9 & 18.1 & 14 & 12.4 & 9 & 6.6 & 12.2 & 13.3 \\
\hline & $1948-14$ & 199.9 & 120.8 & 138.6 & 185.3 & & & & \\
\hline Pre & $1981-14$ & 216.4 & 110.1 & 146.7 & 196.3 & 194.4 & 111.2 & 205.9 & 155.5 \\
\hline & $1948-14$ & 388.3 & 248.4 & 135 & 340 & & & & \\
\hline Mon & $1981-14$ & 304 & 233.7 & 311 & 276.8 & 333.6 & 298.2 & 385 & 312.9 \\
\hline & $1948-14$ & 107.5 & 106.8 & 97.8 & 129.7 & & & & \\
\hline Post & $1981-14$ & 104.3 & 119.5 & 106.7 & 137.6 & 108.4 & 120.8 & 140.5 & 203.3 \\
\hline & $1948-14$ & 39.1 & 45.3 & 52.4 & 43.5 & & & & \\
\hline Win & $1981-14$ & 41.6 & 47 & 58.3 & 43 & 32 & 35 & 35.9 & 38.3 \\
\hline & $1948-14$ & 457.4 & 308.8 & 368.1 & 426 & & & & \\
\hline Ann & $1981-14$ & 416.1 & 254.6 & 334.4 & 355.9 & 388.9 & 334 & 488.2 & 397.9 \\
\hline
\end{tabular}

Table 6: Standard deviation of monthly, seasonal and annual rainfall at different BMD weather stations. 
Citation: Kabir H, Golder J (2017) Rainfall Variability and Its Impact on Crop Agriculture in Southwest Region of Bangladesh. J Climatol Weather

Page 8 of 20

\section{Rainfall Occurrence Trend over Southwest in Bangladesh}

Annual rainfall trend over the southwestern part of Bangladesh and their magnitudes are calculated using Mann-Kendal Tests, Sen's slope estimator and simple linear regression analysis (Least squares).

The annual trend from these three different tests indicates similar results. Predominantly negative trends of annual rainfall are found over the region except Khulna, Satkhira and Khepupara where, trends are going positive with a magnitude of $5.36 \mathrm{~mm} /$ year (at 95\% confidence level, 1948-2014), $1.15 \mathrm{~mm} /$ year (1948-2014) and 12.67 $\mathrm{mm} /$ year (at 90\% confidence level, 1974-2014) respectively (Figures 5i and 5ii).
The highest significant negative trend is observed at Madaripure (at $99 \%$ confidence level) with a magnitude of $15.71 \mathrm{~mm} /$ year over the period 1977-2014. In case of Mongla Mann-Kendal test indicates no significant trend in annual rainfall but a negative Sen's slope $(4.74 \mathrm{~mm} /$ year) (Table 6).

Although in Khulna and Satkhira trends are positive over long period (1948-2014), but it turned to negative over recent climatic period (1981-2014) with a magnitude of $1.43 \mathrm{~mm} /$ year to $4.08 \mathrm{~mm} /$ year respectively (Figure 6).
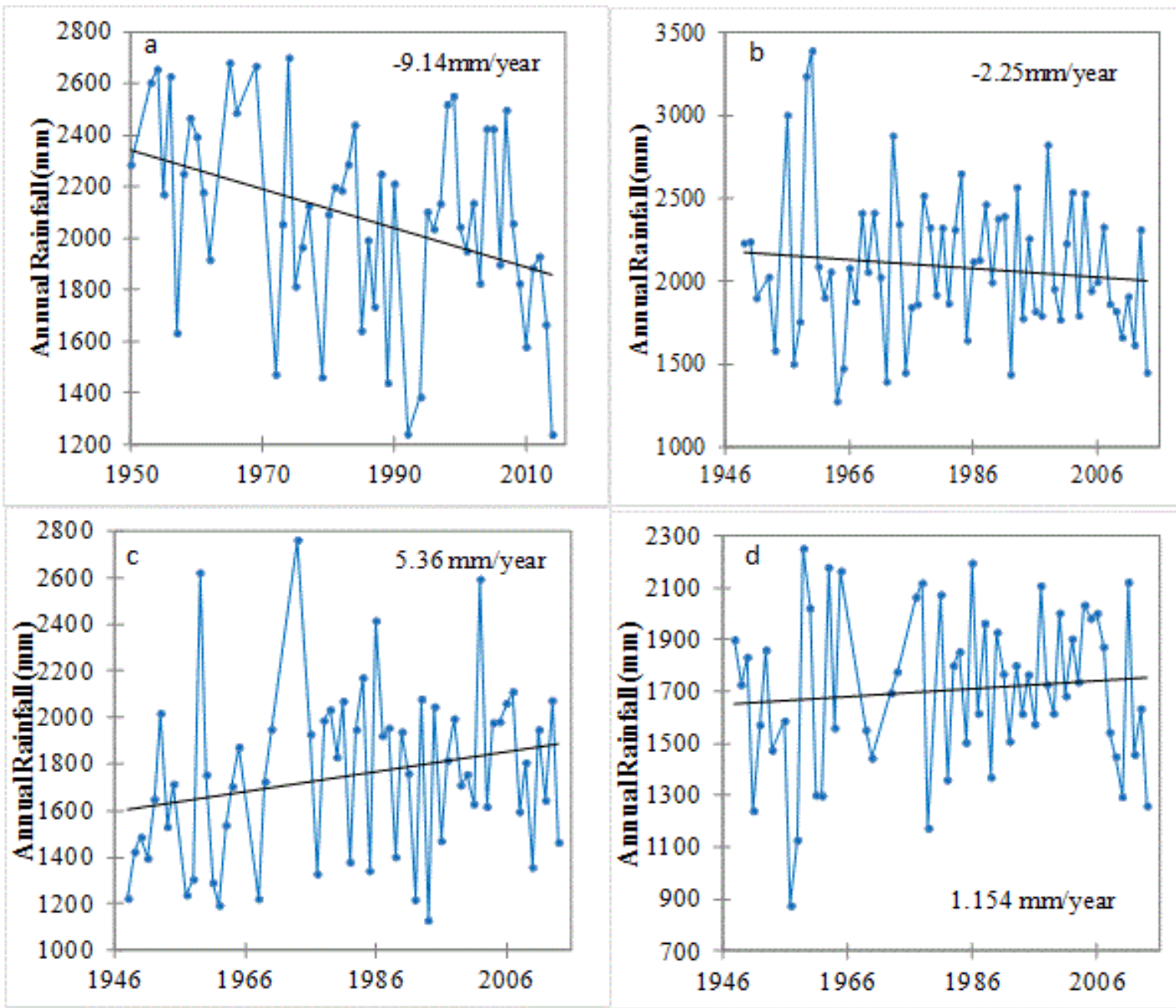

Figure 5i: Annual Rainfall Trend (Mann-Kendal \& Sen's Slope) at (a) Jessore, (b) Barisal, (c) Khulna and (d) Satkhira weather stations of BMD. 
Citation: Kabir H, Golder J (2017) Rainfall Variability and Its Impact on Crop Agriculture in Southwest Region of Bangladesh. J Climatol Weather
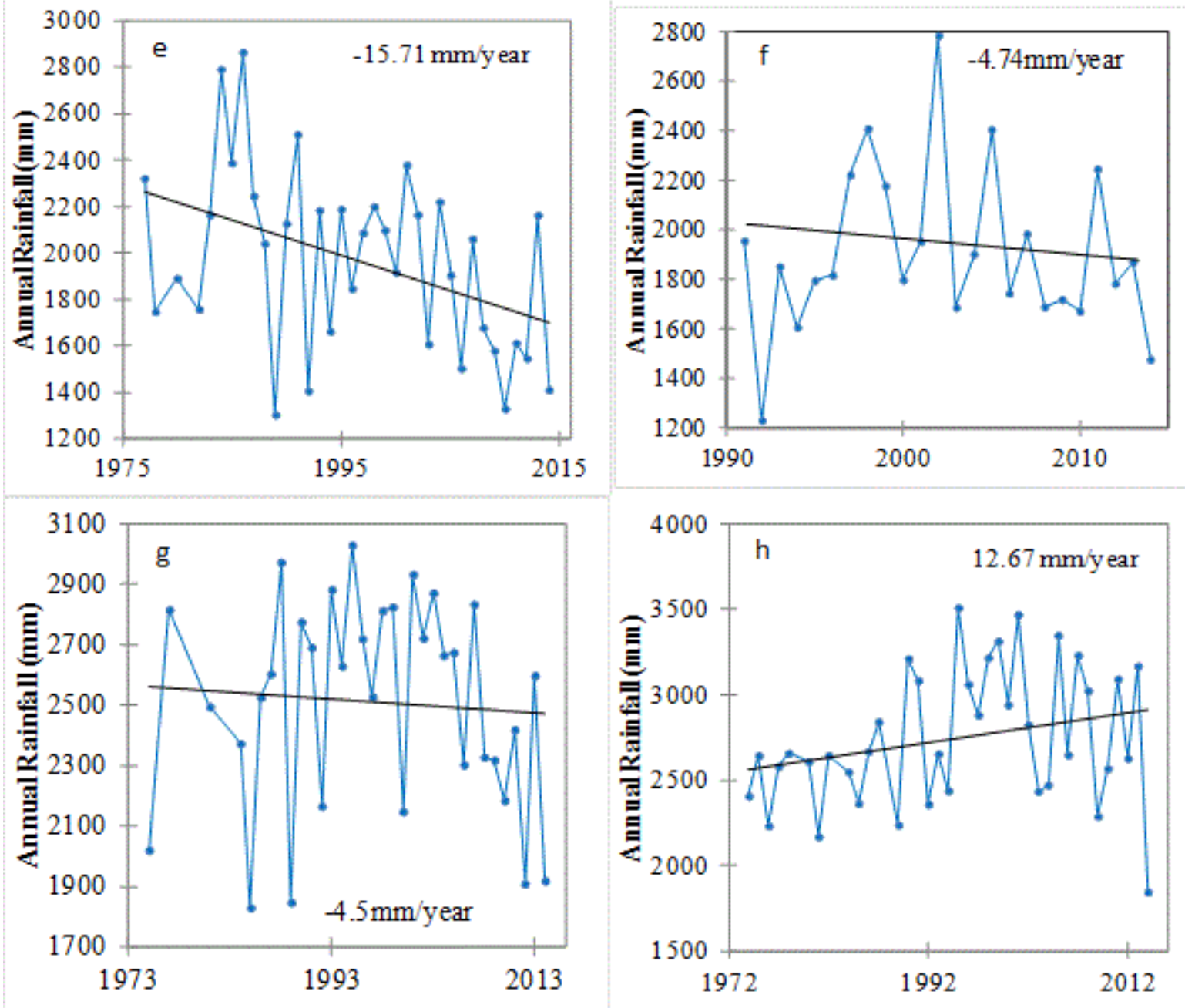

Figure 5ii: Annual Rainfall Trend (Mann-Kendal \& Sen's Slope) at (e) Madaripur, (f) Mongla, (g) Patuakhali and (h) Khepupara weather stations of BMD.

Mann-Kendal and Sen's slope tests are also applied over the annual rainfall time series of TRMM records of different study points. Significant negative trends are observed at Gopalganj, Madaripur, Barisal, Jhalakathi, Patuakhali, Barguna and Sibsa point. While other places negative slopping with no significance.

For the month of January, February, March, November and December no significant trend (Mann-Kendal) is observed for maximum cases. While for rest of the months significant trend is found for maximum cases. In these months at Khulna, Satkhira and Khepupara trends are observed positive (i.e., increase) for maximum cases but in other stations significant negative trends are found for maximum cases.

Trends in seasonal rainfall also varied over the study area. In Premonsoon season highest negative trend is observed at Madaripure
(6.91 mm/year, at $99 \%$ confidence level), and positive at Satkhira (1.46 $\mathrm{mm} /$ year, at $99 \%$ confidence level). But in Monsoon highest negative trend is observed at Jessore (10.49 mm/year, at $99 \%$ confidence level) and positive at Khepupara ( $4.85 \mathrm{~mm} /$ year, at $99 \%$ confidence level). In Post-monsoon trends turned positive for maximum cases, but only significantly negative at Jessore. And in winter significant negative trends are present at Madaripur, Mongla and Patuakhali but positive over Khulna and Satkhira (Table 7).

Station wise linear regression analysis of monthly, seasonal and annual rainfall is under study and negative trends are observed for maximum cases. In Khulna annual trend is positive over long term period but becomes negative over the recent climatic period. Monthly and seasonal trends are anomalous but predominantly negative for maximum cases (Table 8). 
Citation: Kabir H, Golder J (2017) Rainfall Variability and Its Impact on Crop Agriculture in Southwest Region of Bangladesh. J Climatol Weather Forecasting 5: 196. doi:10.4172/2332-2594.1000196
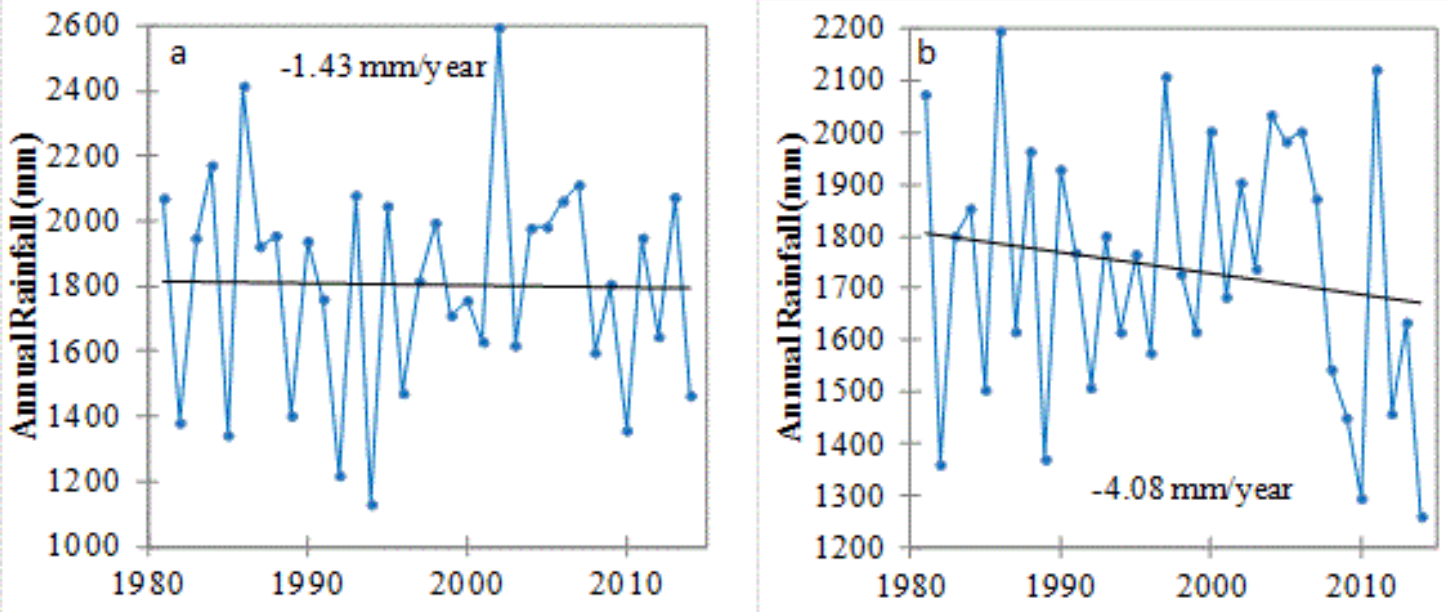

Figure 6: Annual rainfall trend over recent climatic period (1981-2014) at (a) Khulna and (b) Satkhira.

\begin{tabular}{|c|c|c|c|c|c|c|c|c|}
\hline Time Period & Jessore & Satkhira & Khulna & Barisal & Madaripur & Mongla & Patuakhali & Khepupara \\
\hline Jan & - & - & - & - & - & $-0.24^{* * *}$ & - & - \\
\hline Feb & - & - & $0.05^{* *}$ & - & $-0.55^{* * *}$ & $-1.18^{* * *}$ & - & - \\
\hline Mar & -0.178 & 0.06 & - & 0.02 & $-0.52^{* *}$ & $-1.06^{* * *}$ & - & - \\
\hline Apr & $-0.86^{* * *}$ & 0.15 & $-0.39^{* *}$ & 0.06 & $-3.73^{* * *}$ & $-1.33^{* * *}$ & $-2.42^{* * *}$ & $-1.06^{\star *}$ \\
\hline May & $0.63^{* *}$ & $1.25^{\star \star \star *}$ & $0.68^{\star \star \star *}$ & -0.06 & $-3.29^{\star \star \star *}$ & $2.26^{* *}$ & -1.48 & 0.673 \\
\hline Jun & $-3.02^{* * *}$ & 0.02 & $-1^{* * *}$ & $-1.01^{* * *}$ & $-2.64^{* *}$ & $-4.38^{* * *}$ & $-4.89^{* * *}$ & -0.495 \\
\hline Jul & $-3.91^{* * * *}$ & 0.14 & 0.273 & -0.22 & $-3.16^{* * *}$ & $2.81^{* *}$ & -0.18 & 0.919 \\
\hline Aug & $-2.95^{* * *}$ & -0.17 & $1.8^{* * *}$ & -0.26 & $-2.52^{* \star *}$ & -0.65 & $-1.6^{*}$ & -0.722 \\
\hline Sep & $-1.11^{* *}$ & $1.14^{* * *}$ & $2.33^{* * *}$ & $-0.5^{*}$ & -0.02 & 2.44 & -0.31 & $3.72^{* * *}$ \\
\hline Oct & $-0.86^{* *}$ & -0.25 & $0.71^{* * *}$ & $-0.84^{* *}$ & $1.53^{* * *}$ & $1.51^{*}$ & $4.5^{* * *}$ & $4.86^{* * *}$ \\
\hline Nov & - & - & - & - & - & $-0.09^{*}$ & $-1.13^{\star * *}$ & - \\
\hline Dec & - & - & - & - & - & - & - & - \\
\hline Pre & -0.34 & $1.46^{* * *}$ & 0.143 & 0.293 & $-6.91^{* * *}$ & -3.53 & $-4.66^{* * *}$ & -0.58 \\
\hline Mon & $-8.49^{* * * *}$ & 0.77 & $3.69^{*+* x}$ & $-2.02^{* * * *}$ & $-7.80^{\star *}$ & 0.06 & -3.6 & $4.85^{* * *}$ \\
\hline Post & $-0.99^{* *}$ & - & $1.15^{* \star *}$ & -0.469 & $1.95^{* * *}$ & 0.2 & $2.08^{* * *}$ & $4.44^{* * *}$ \\
\hline Win & 0.05 & $0.39^{* * *}$ & $0.33^{* * *}$ & - & $-0.81^{* * *}$ & $-1.27^{* * *}$ & $-0.37^{* *}$ & 0.11 \\
\hline Ann. & $-9.14^{\star \star *}$ & 1.15 & $5.36^{* *}$ & -3.67 & $-15.71^{* * *}$ & -4.734 & $-4.5^{*}$ & $12.67^{*}$ \\
\hline
\end{tabular}

Table 7: Mann-Kendal trend test results over the study area. 
Citation: Kabir H, Golder J (2017) Rainfall Variability and Its Impact on Crop Agriculture in Southwest Region of Bangladesh. J Climatol Weather Forecasting 5: 196. doi:10.4172/2332-2594.1000196

Page 11 of 20

\begin{tabular}{|c|c|c|c|c|c|c|c|c|c|}
\hline \multicolumn{2}{|c|}{ Time Period } & \multirow{2}{*}{$\begin{array}{l}\text { Jessore } \\
0.01\end{array}$} & \multirow{2}{*}{$\begin{array}{l}\text { Satkhira } \\
0.13\end{array}$} & \multirow{2}{*}{$\begin{array}{l}\text { Khulna } \\
0.14\end{array}$} & \multirow{2}{*}{$\begin{array}{l}\text { Barisal } \\
-0.01\end{array}$} & \multirow{3}{*}{$\begin{array}{l}\text { Madaripur } \\
(1977-2014)\end{array}$} & \multirow{3}{*}{$\begin{array}{l}\text { Mongla } \\
(1991-2014)\end{array}$} & \multirow{3}{*}{\begin{tabular}{|l}
$\begin{array}{l}\text { Patuakhali } \\
(1973-2014)\end{array}$ \\
-0.08
\end{tabular}} & \multirow{3}{*}{$\begin{array}{l}\text { Khepupara } \\
(1974-2014)\end{array}$} \\
\hline Jan & $1948-14$ & & & & & & & & \\
\hline & $1981-14$ & -0.05 & -0.18 & -0.23 & -0.12 & & & & \\
\hline \multirow[t]{2}{*}{ Feb } & $1948-14$ & -0.26 & 0.11 & 0.28 & 0.01 & \multirow[t]{2}{*}{-0.69} & \multirow[t]{2}{*}{-1.56} & \multirow[t]{2}{*}{-0.02} & \multirow[t]{2}{*}{-0.01} \\
\hline & $1981-14$ & -0.27 & -0.569 & -0.803 & -0.61 & & & & \\
\hline \multirow[t]{2}{*}{ Mar } & $1948-14$ & 0.14 & 0.27 & 0.13 & -0.02 & \multirow[t]{2}{*}{-1.21} & \multirow[t]{2}{*}{-2.82} & \multirow[t]{2}{*}{0.01} & \multirow[t]{2}{*}{-0.55} \\
\hline & $1981-14$ & -1.40 & -0.31 & -1.21 & -0.95 & & & & \\
\hline \multirow[t]{2}{*}{ Apr } & $1948-14$ & -1.39 & 0.11 & -0.75 & 0.04 & \multirow[t]{2}{*}{-4.32} & \multirow[t]{2}{*}{-1.59} & \multirow[t]{2}{*}{-3.02} & \multirow[t]{2}{*}{-1.40} \\
\hline & $1981-14$ & -4.36 & -2.51 & -3.89 & -3.64 & & & & \\
\hline \multirow[t]{2}{*}{ May } & $1948-14$ & 0.60 & 0.68 & 0.73 & 0.06 & \multirow[t]{2}{*}{-1.50} & \multirow[t]{2}{*}{2.05} & -2.92 & 2.34 \\
\hline & $1981-14$ & -2.49 & 1.45 & -0.06 & -0.32 & & & & \\
\hline Jun & $1948-14$ & -4.02 & -0.43 & -0.45 & -1.69 & -3.76 & -3.89 & -4.96 & -0.30 \\
\hline & $1981-14$ & 1.84 & -2.48 & -2.73 & -3.22 & & & & \\
\hline Jul & $1948-14$ & -3.84 & 0.15 & -0.16 & -0.71 & -2.91 & 3.02 & -0.62 & 1.29 \\
\hline & $1981-14$ & -1.74 & 0.02 & 2.06 & -0.86 & & & & \\
\hline Aug & $1948-14$ & -3.15 & 0.19 & 2.03 & -0.77 & -3.39 & 1.05 & -2.42 & -0.35 \\
\hline & $1981-14$ & -1.28 & -0.8 & 0.39 & -3.54 & & & & \\
\hline Sep & $1948-14$ & -1.04 & 0.81 & 2.24 & -0.31 & 0.77 & 2.67 & -1.26 & 3.26 \\
\hline & $1981-14$ & 0.41 & 0.57 & 3.94 & 2.77 & & & & \\
\hline Oct & $1948-14$ & -1.26 & 0.20 & 0.78 & -0.54 & 1.57 & 1.75 & 4.23 & 4.17 \\
\hline & $1981-14$ & 1.03 & 1.55 & 1.54 & 1.18 & & & & \\
\hline Nov & $1948-14$ & -0.44 & 0.04 & 0.22 & 0.22 & -0.11 & -1.35 & -2.39 & -0.50 \\
\hline & $1981-14$ & -0.49 & -0.37 & -0.57 & -1.22 & & & & \\
\hline Dec & $1948-14$ & 0.04 & -0.03 & 0.05 & -0.04 & -0.16 & 0.07 & -0.38 & -0.08 \\
\hline & $1981-14$ & -0.40 & -0.47 & -0.43 & -0.26 & & & & \\
\hline Pre & $1948-14$ & -0.79 & 1.21 & 0.25 & 0.83 & -7.03 & -2.36 & -6.76 & 0.38 \\
\hline & $1981-14$ & -8.24 & -1.36 & -5.17 & -4.71 & & & & \\
\hline Mon & $1948-14$ & -12.05 & 1.32 & 4.10 & -3.83 & -10.41 & 2.847 & -3.24 & 4.32 \\
\hline & $1981-14$ & -0.77 & -2.69 & 5.02 & -5.76 & & & & \\
\hline Post & $1948-14$ & -1.70 & 0.29 & 1.02 & -0.43 & 1.49 & 0.40 & 1.84 & 3.67 \\
\hline & $1981-14$ & 0.54 & 1.18 & 0.97 & -0.09 & & & & \\
\hline Win & $1948-14$ & 0.05 & 0.53 & 0.65 & -0.25 & -0.90 & -1.75 & -0.42 & 0.05 \\
\hline & $1981-14$ & -0.73 & -1.14 & -1.46 & -0.92 & & & & \\
\hline Ann & $1948-14$ & -7.31 & -0.06 & 6.41 & -2.70 & -12.94 & -0.92 & -3.00 & 8.86 \\
\hline & $1981-14$ & -9.18 & 0.03 & -0.64 & -10.48 & & & & \\
\hline
\end{tabular}

Table 8: Linear regression trend values of monthly, seasonal, and annual rainfall. 
Citation: Kabir H, Golder J (2017) Rainfall Variability and Its Impact on Crop Agriculture in Southwest Region of Bangladesh. J Climatol Weather Forecasting 5: 196. doi:10.4172/2332-2594.1000196

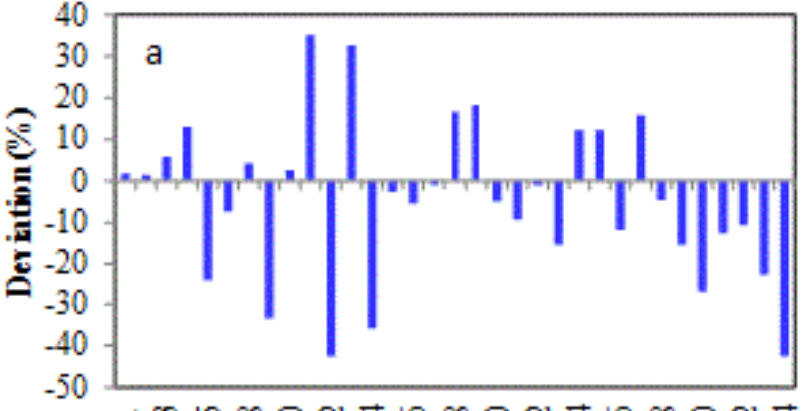

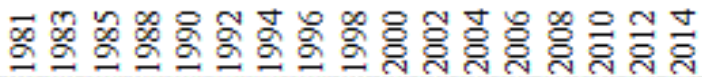

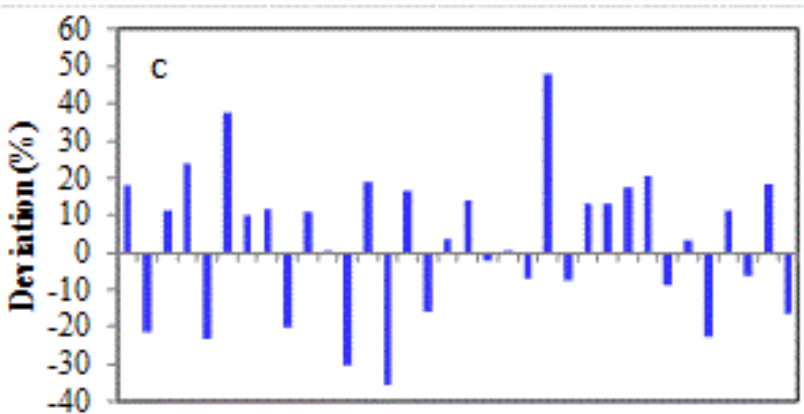

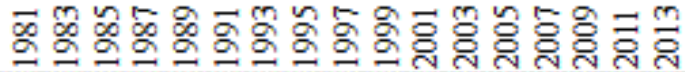
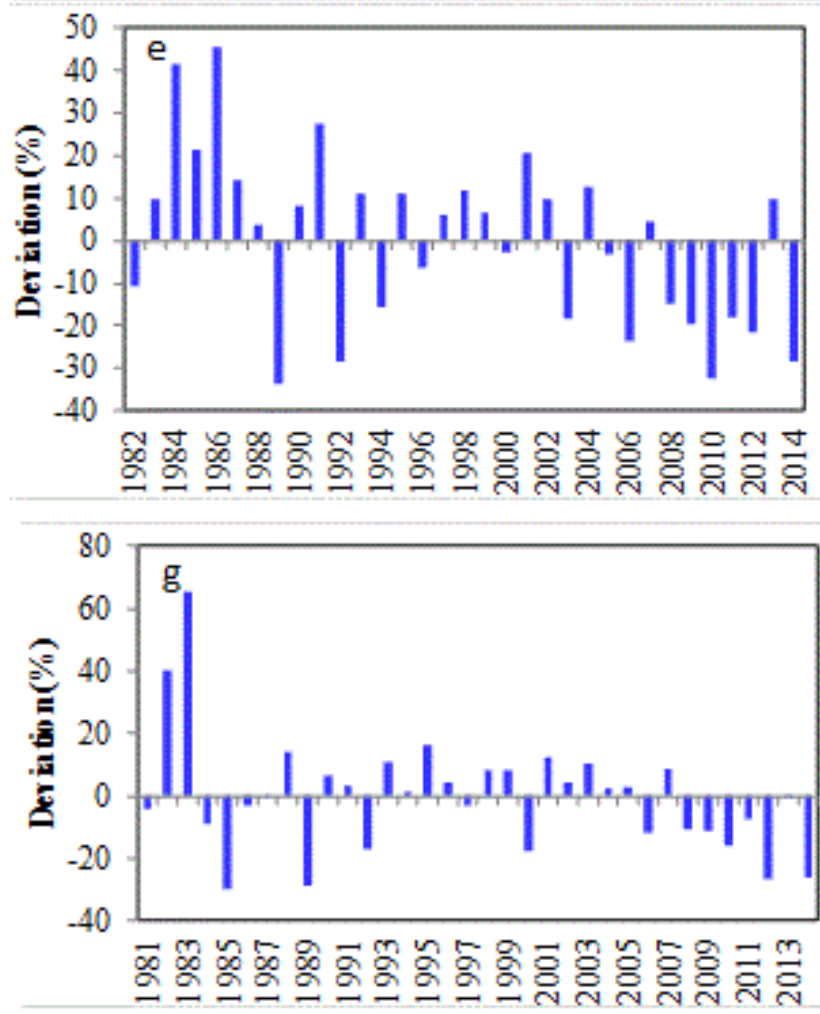
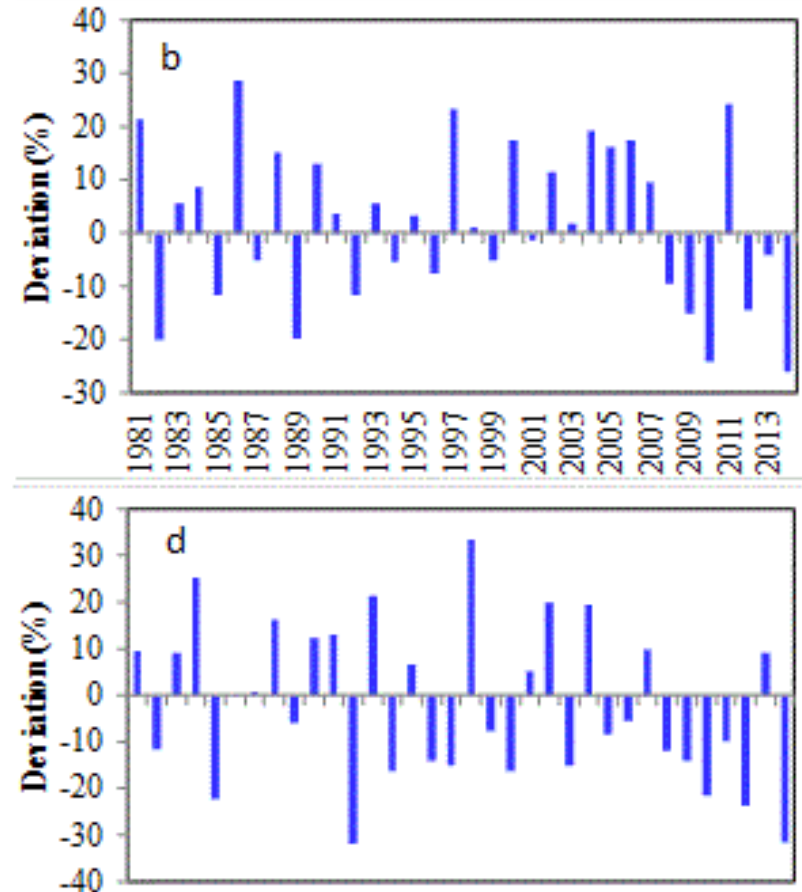

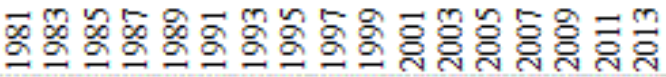
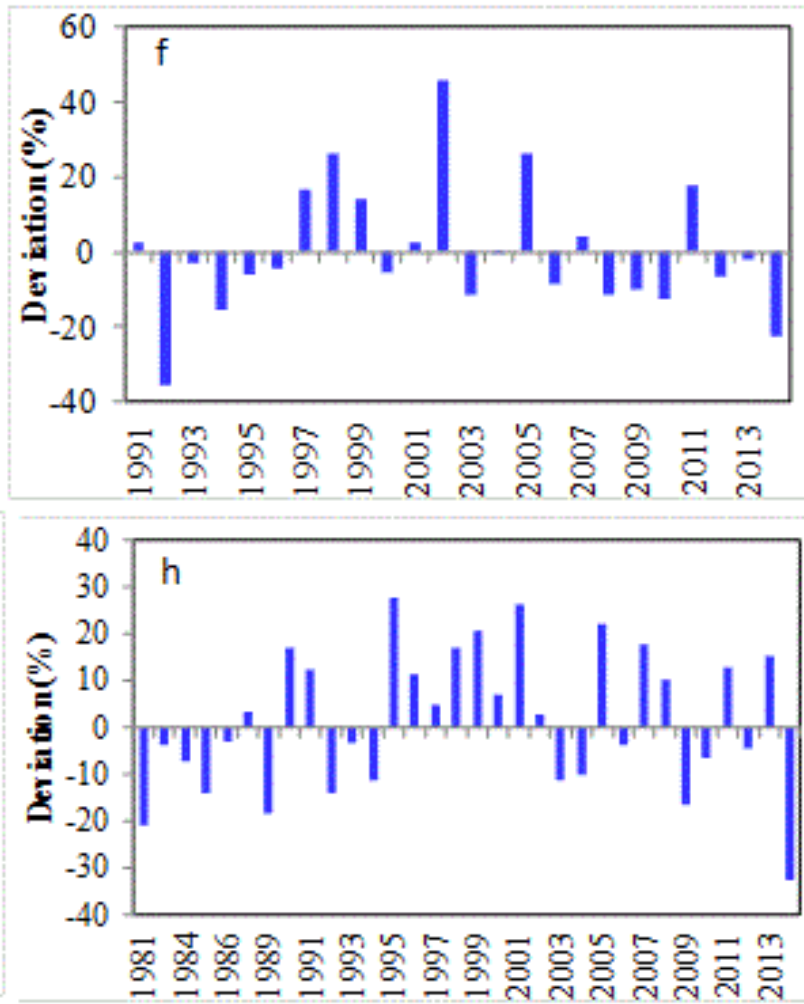

Figure 7: Annual rainfall deviation (\%) in recent period at (a) Jessore, (b) Satkhira, (c) Khulna, (d) Barisal, (e) Madaripur, (f) Mongla (1991-2014), (g) Patuakhali and (h) Khepupara weather stations of BMD. 
Citation: Kabir H, Golder J (2017) Rainfall Variability and Its Impact on Crop Agriculture in Southwest Region of Bangladesh. J Climatol Weather

Page 13 of 20

\section{Deviation of Rainfall in Recent Period}

Rainfall in the southwestern part of Bangladesh is very much variable in nature. In recent time annual rainfall varies within a range of $48.1 \%$ to $-42.6 \%$. Most wide annual deviation is observed in Khulna from $48.6 \%$ to $-35.5 \%$, and most narrow deviation is found in Satkhira, from $28.7 \%$ to $-26.1 \%$ (Figures 6 and 7 ).

Rainfall deviation is wider in seasonal scale than annual scale. It is observed lowest in monsoon and highest in winter, i.e., rainfall is most consistent in monsoon and most variable in winter. In monsoon positive deviation is found as high as $72.0 \%$ in Madaripur and negative deviation as low as $-43.0 \%$ in Khulna.

In pre-monsoon it is found within $216.5 \%$ (Patuakhali) to $-71.6 \%$ (Barisal), and in post-monsoon within $181.9 \%$ (Satkhira) to $-100.0 \%$ (Jessore \& Mongla), and in winter within $586.0 \%$ (Khulna) to $-100.0 \%$ (all station) (Table 9).

\begin{tabular}{|c|c|c|c|c|c|c|}
\hline Station & Deviation Category & Pre-monsoon & Monsoon & Post-monsoon & Winter & Annual \\
\hline \multirow[b]{2}{*}{ Jessore } & Highest (\%) & 114 & 40.3 & 88 & 399.6 & 35.1 \\
\hline & Lowest (\%) & -66.2 & -42.9 & -100 & -100 & -42.6 \\
\hline \multirow[b]{2}{*}{ Satkhira } & Highest (\%) & 117.3 & 40.7 & 181.9 & 278.1 & 28.7 \\
\hline & Lowest (\%) & -51.7 & -33.5 & -95.2 & -100 & -26.1 \\
\hline \multirow[b]{2}{*}{ Khulna } & Highest (\%) & 173.7 & 61.4 & 152.7 & 586 & 48.1 \\
\hline & Lowest (\%) & -61 & -43 & -94.6 & -100 & -35.5 \\
\hline \multirow[b]{2}{*}{ Barisal } & Highest (\%) & 142.5 & 43.3 & 145.1 & 465.1 & 33.4 \\
\hline & Lowest (\%) & -71.6 & -30.7 & -95.1 & -100 & -32 \\
\hline \multirow[b]{2}{*}{ Madaripur } & Highest (\%) & 94.4 & 72 & 121.2 & 285.6 & 45.4 \\
\hline & Lowest (\%) & -54.9 & -40 & -91 & -100 & -33.8 \\
\hline \multirow[b]{2}{*}{ Mongla } & Highest (\%) & 67.2 & 62.1 & 97.9 & 216.3 & 46 \\
\hline & Lowest (\%) & -57.5 & -31.7 & -100 & -100 & -35.5 \\
\hline \multirow[b]{2}{*}{ Patuakhali } & Highest (\%) & 216.5 & 71.9 & 119.5 & 251.8 & 39.4 \\
\hline & Lowest (\%) & -68.3 & -32.3 & -92.8 & -100 & -29.8 \\
\hline \multirow[b]{2}{*}{ Khepupara } & Highest (\%) & 100.4 & 28.7 & 160.4 & 388.9 & 27.9 \\
\hline & Lowest (\%) & -57.7 & -28.8 & -93.3 & -100 & -32.8 \\
\hline
\end{tabular}

Table 9: Seasonal and annual extreme rainfall deviation (\%) in recent time.

\section{Trend of 99th Percentile of Seasonal and Annual Rainfall}

Trend of 99th percentile of seasonal and annual rainfall in southwestern part of the country is under study. The annual 99th percentile is on a negative trend over Jessore, Barisal, Madaripur and Patuakhali, but positive over Satkhira, Khulna, Mongla and Khepupara.

Highest significant positive trend is observed at Mongla (0.79) at $90 \%$ confidence level, while highest negative magnitude is observed at Madaripur (-0.32) (Figures 8i and 8ii).
In pre-monsoon season the trend is negative at maximum stations except Barisal. In case of Khulna and Satkhira it is positive over long period but becomes negative over recent period. In this season highest significant negative magnitude $(-0.61)$ is observed at Madaripur at $95 \%$ confidence level. In monsoon trend direction is almost synclined with the annual except Satkhira, where annual trend is positive but becomes negative in monsoon.

In this season highest negative magnitude is observed at Patuakhali $(-0.68)$ and positive at Mongla (0.40) (Table 10). 
Citation: Kabir H, Golder J (2017) Rainfall Variability and Its Impact on Crop Agriculture in Southwest Region of Bangladesh. J Climatol Weather Forecasting 5: 196. doi:10.4172/2332-2594.1000196
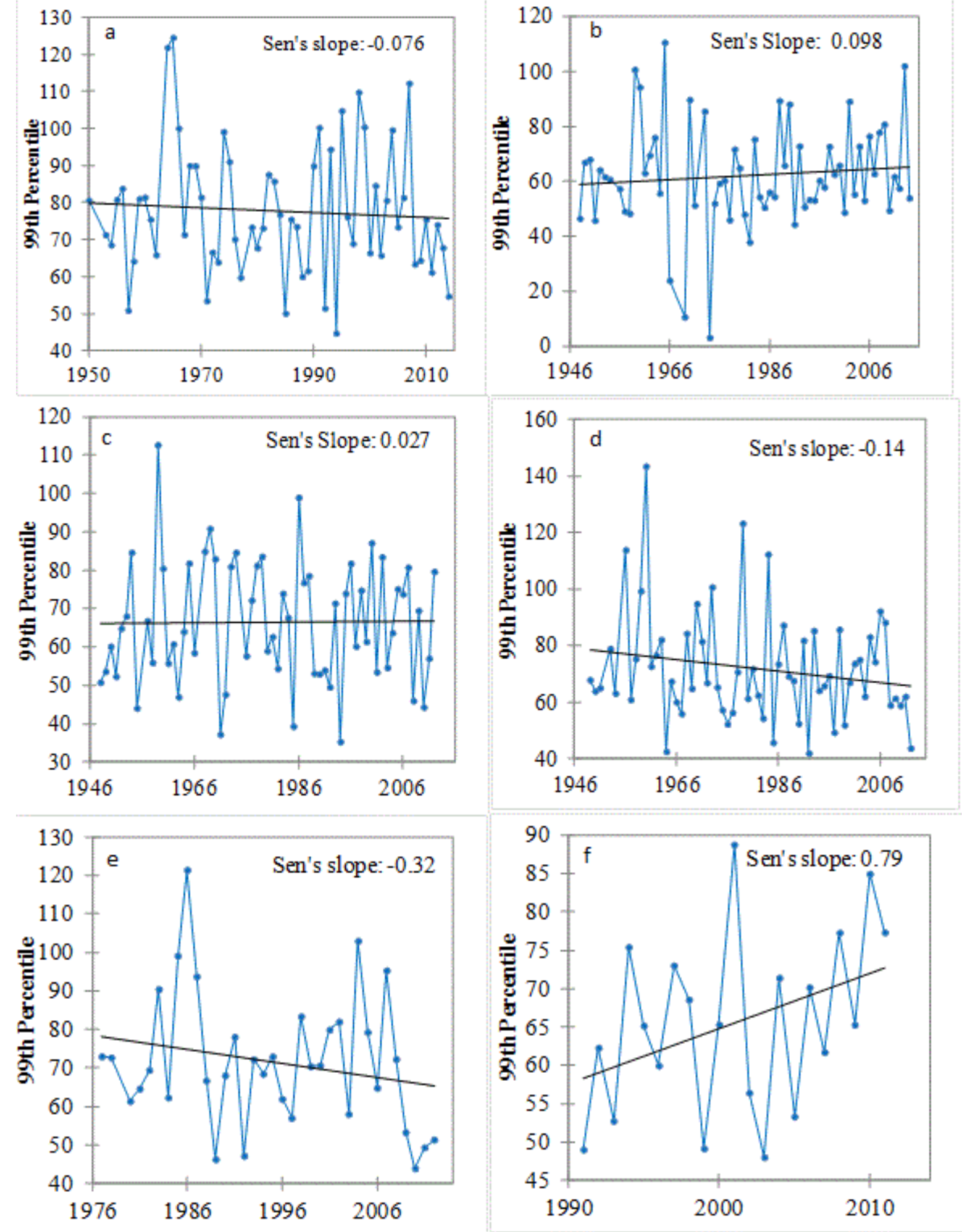

Figure 8i: Trend of 99th Percentile of annual rainfall at (a) Jessore, (b) Satkhira, (c) Khulna, (d) Barisal, (e) Madaripur and (f) Mongla weather stations of BMD. 
Citation: Kabir H, Golder J (2017) Rainfall Variability and Its Impact on Crop Agriculture in Southwest Region of Bangladesh. J Climatol Weather
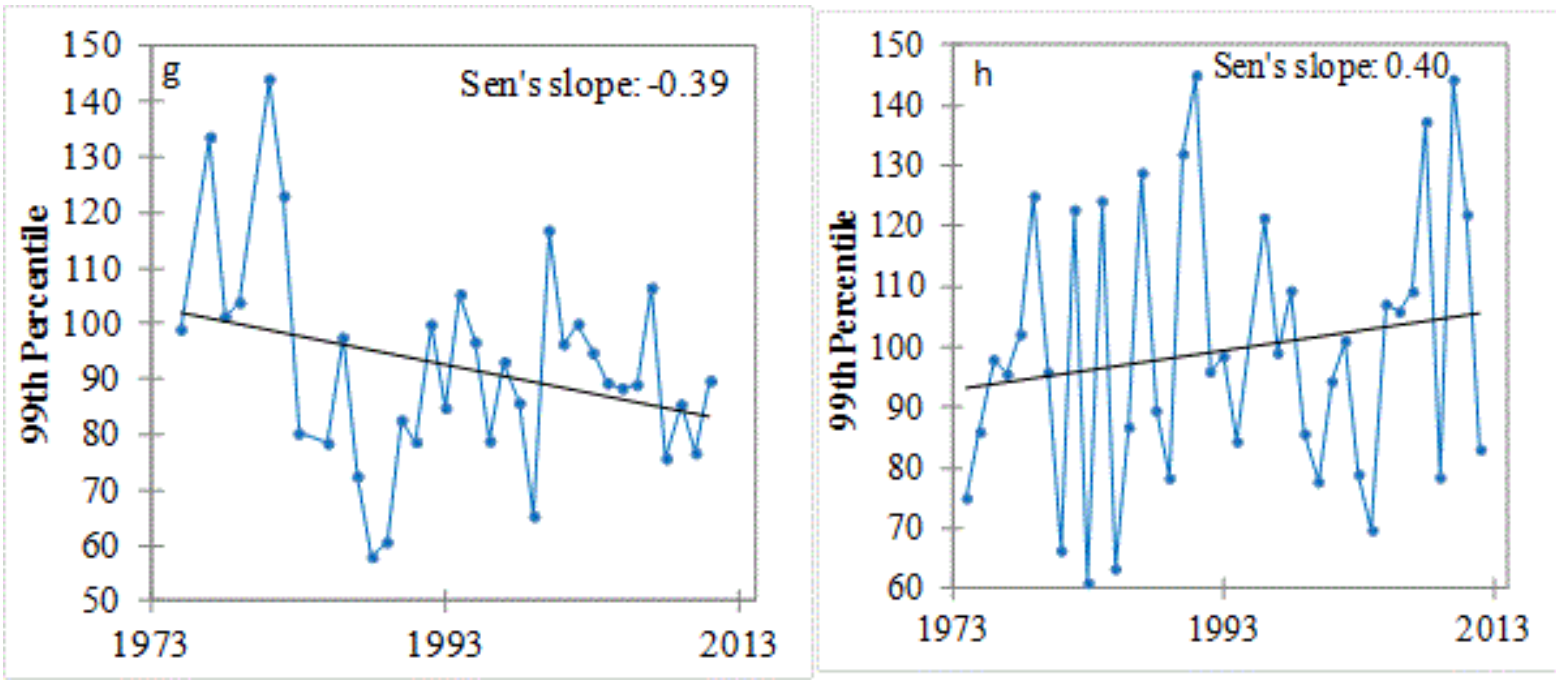

Figure 8ii: Trend of 99th Percentile of annual rainfall at (g) Patuakhali and (h) Khepupara weather stations of BMD.

\begin{tabular}{|l|l|l|l|l|}
\hline Station & Time Range & Pre-monsoon & Monsoon & Annual \\
\hline \multirow{3}{*}{ Jessore } & $1948-2014$ & -0.18 & -0.61 & -0.08 \\
\cline { 2 - 5 } & $1981-2014$ & -0.71 & -0.07 & -0.22 \\
\hline \multirow{3}{*}{ Satkhira } & $1948-2014$ & 0.11 & -0.67 & 0.10 \\
\cline { 2 - 5 } & $1981-2014$ & -0.10 & -0.19 & $0.41^{*}$ \\
\hline \multirow{2}{*}{ Khulna } & $1948-2014$ & 0.04 & 0.01 & 0.03 \\
\cline { 2 - 5 } & $1981-2014$ & -0.55 & 0.37 & 0.41 \\
\hline \multirow{3}{*}{ Barisal } & $1948-2014$ & 0.05 & -0.19 & -0.14 \\
\cline { 2 - 5 } Madaripur & $1981-2014$ & 0.07 & -0.49 & -0.14 \\
\hline Mongla & $1977-2014$ & $-0.61^{* *}$ & -0.32 & -0.32 \\
\hline Patuakhali & $1991-2014$ & -0.23 & 0.40 & $0.79^{*}$ \\
\hline Khepupara & $1973-2014$ & -0.39 & -0.68 & -0.39 \\
\hline "* Significant at 95\% confidence level; *Significant at 90\% confidence level. & -0.20 & 0.08 & 0.40 \\
\hline
\end{tabular}

Table 10: Mann-Kendal and Sen's slope test result of 99th percentile of seasonal and annual rainfall at different BMD stations.

\section{Trend of Seasonal and Annual Heavy Rainfall Days}

Trend is also studied on seasonal and annual heavy rain days over the study area. Only significant negative trends are observed in Jessore (at 99\% confidence level) and Madaripur (90\% confidence level) over pre-monsoon, monsoon and annual time period (Tables 10 and 11). In other stations in pre-monsoon and monsoon season no trends are observed. On annual scale slight positive trend is observed in Khulna and slight negative in Barisal and Patuakhali (Figures 9i and 9ii). 
Citation: Kabir H, Golder J (2017) Rainfall Variability and Its Impact on Crop Agriculture in Southwest Region of Bangladesh. J Climatol Weather Forecasting 5: 196. doi:10.4172/2332-2594.1000196
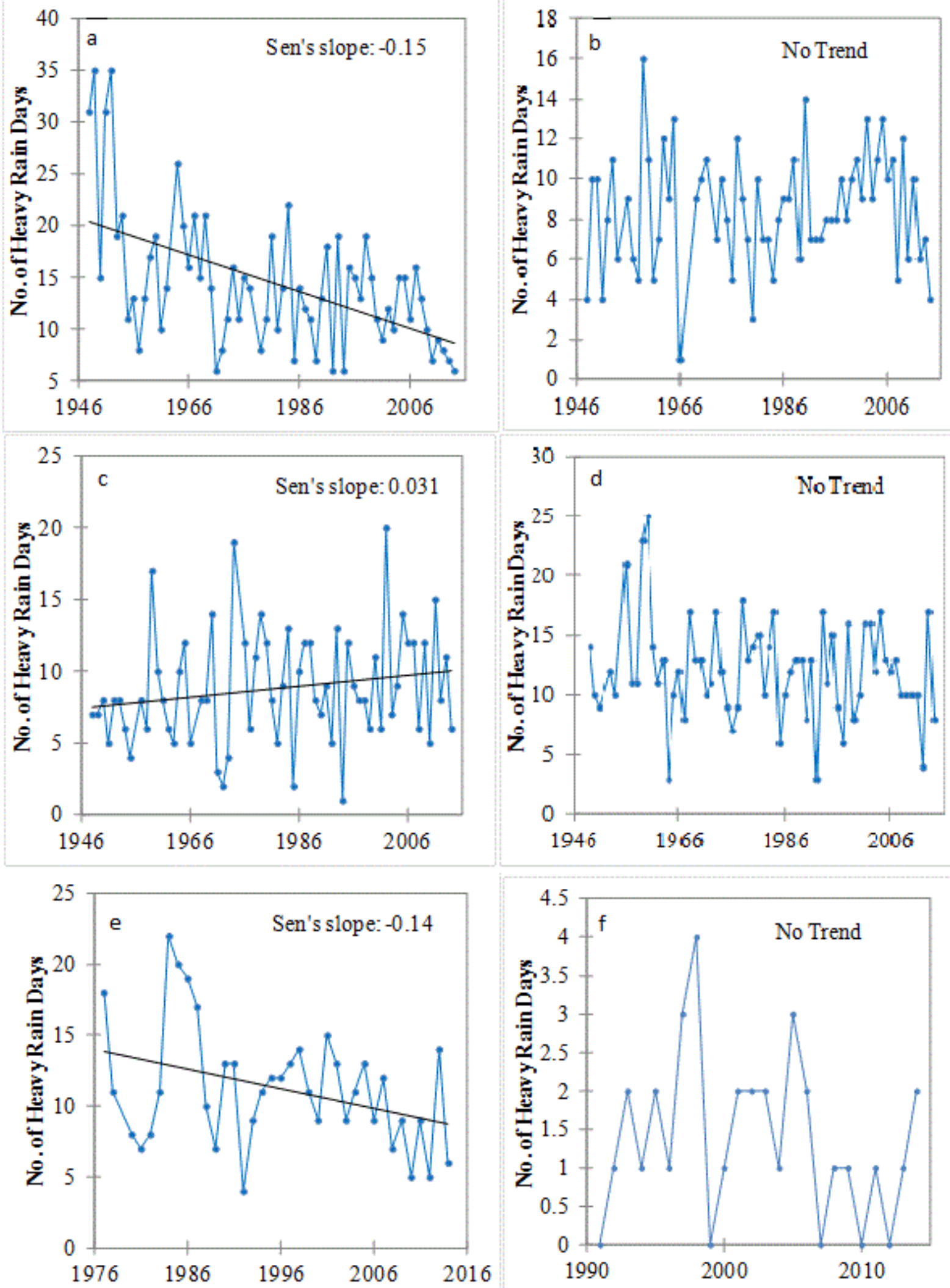

Figure 9i: Trend of annual heavy rain days at (a) Jessore, (b) Satkhira, (c) Khulna, (d) Barisal, (e) Madaripur and (f) Mongla weather stations of BMD. 

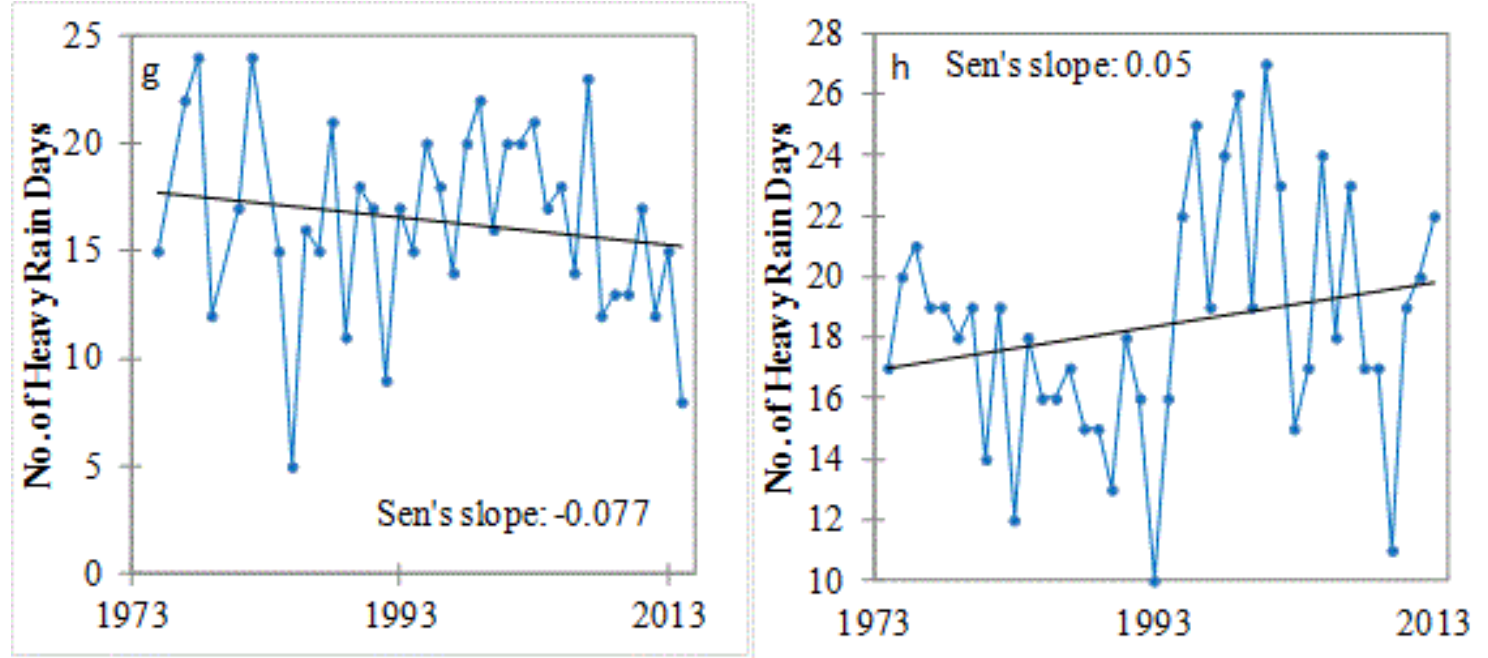

Figure 9ii: Trend of annual heavy rain days at (g) Patuakhali and (h) Khepupara weather stations of BMD.

\begin{tabular}{|l|l|l|l|l|}
\hline Station & Time Range & Annual & Pre-monsoon & Monsoon \\
\hline Jessore & $1948-2014$ & $-0.15^{* * *}$ & $-0.12^{* * *}$ & $-0.12^{* * *}$ \\
\hline Satkhira & $1948-2014$ & 0 & 0 & 0 \\
\hline Khulna & $1948-2014$ & 0.031 & 0 & 0.018 \\
\hline Barisal & $1948-2014$ & -0.023 & 0 & 0 \\
\hline Madaripue & $1977-2014$ & $-0.14^{*}$ & $-0.059^{*}$ & $-0.066^{*}$ \\
\hline Mongla & $1991-2014$ & 0 & 0 & -0.063 \\
\hline Patuakhali & $1973-2014$ & -0.077 & 0 & 0 \\
\hline Khepupara & $1974-2014$ & 0.05 & 0 & 0 \\
\hline *** Significant at 99\% confidence level; *Significant at 90\% confidence level. & & 0 \\
\hline
\end{tabular}

Table 11: Mann-Kendal and Sen's slope test result of seasonal and annual heavy rain days at different BMD stations.

\section{Overall Rainfall Scenario over the Southwest Region}

Statistical analysis of rainfall variability over the southwestern part of Bangladesh exhibits an overall decreasing scenario, except the Khepupara station which lies in the exposed coastal zone while other stations lies in the interior part. At Khulna and Satkhira, though the rainfall trend is found positive over the long term period but turned into negative $(-4.08 \mathrm{~mm} /$ year at Khulna and $-1.43 \mathrm{~mm} /$ year at Satkhira) in recent climatic period. It clearly represents a major turning point in rainfall variability in recent times after 1980s. Magnitude of decreasing trend is highest in the most upper part of southwest region like places in Jessore $(-9.4 \mathrm{~mm} /$ year at $99 \%$ confidence lever) and Madaripur (-15.71 mm/year at $99 \%$ confidence level) (Table 3). Besides, some other specific seasonal specialties are also observed. In pre-monsoon period over the places of Khulna, Satkhira and Barisal rainfall trends are positive, but shifted to a negative slopping after 1980s. While in other places of Mongla, Madaripur, and Patuakhali, recent (1981-2014) pre-monsoon trends are significantly negative except the exterior coastal station of
Khepupara. Earlier longer term scenarios are not possible to assess here due to non-availability of long term records. But in monsoon season, rainfall trend is almost similar to annual trend except Khulna, Satkhira and Mongla stations, where though the annual trend is negative but monsoon trend is positive. It indicates monsoon rain intensification in fore southwestern part of the region. In winter season, a major turning point in trend is also prominent. Stations having long term record, e.g. Jessore, Khulna, Satkhira exhibit an increasing trend over long term period but turned to a decreasing one after 1980s (Table 3). Other young stations also exhibit negative trends except Khepupara. It represents a major change in recent climatic condition.

TRMM satellites records also represent significant negative trends (Table 2) with higher magnitudes over recent (1998-2014) times. Annual 99th percentile trend in most of the cases is synclined with the trend of annual rainfall, except Mongla, where rainfall is going on a decreasing trend but 99th percentile is on an increasing trend, i.e., extreme rainfall events are intensifying. In case of Khulna and Satkhira 
Citation: Kabir H, Golder J (2017) Rainfall Variability and Its Impact on Crop Agriculture in Southwest Region of Bangladesh. J Climatol Weather

Page 18 of 20

annual rainfall trend is positive over long period (1948-2014) but turned into negative over recent (1981-2014) period. But 99th percentile of these two stations is positive over long period and recent period. Moreover the magnitude is further intensified from 0.10 to 0.41 in Satkhira and 0.03 to 0.42 in Khulna. It reveals that extreme rainfall events are intensifying over Khulna and Satkhira in recent time.

\section{Impact of present rainfall trend on crop agriculture in the study area}

The present research identified that the crop agriculture in the study area is greatly influenced by the rainfall pattern as well as the local hydrologic and geomorphic characteristics. The local environmental stress together with rainfall anomaly and changing pattern continues to build up a severe threat to crop agricultural practices.
Impact of monsoon rainfall variability on crop agriculture: As the study area is a part of floodplain delta, there is always a risk of flooding. Most of the land of the study area is between medium high to medium low and thus are flooded to different degrees, from less than $90 \mathrm{~cm}$ to more than $180 \mathrm{~cm}$. But it was not a major concern at earlier times. But the current problem is becoming worse is the poor drainage condition (opinion of local people), due to siltation on river bed. It has made rivers lower capacitate to drain water, and thus a little heavy rainfall causes serious flooding condition. And it is becoming intensive day by day. In the current year 2015 rainfall was comparatively higher that has caused severe flooding and crop damage. If we focus on the monsoon rainfall trend (Figure 10) over Khulna district, it has started to increase recently. It is intensifying the risk of similar crop damage. And day by day if the drainage condition becomes poorer and monsoon rain intensified will impose tremendous risk to monsoon season crop cultivation.
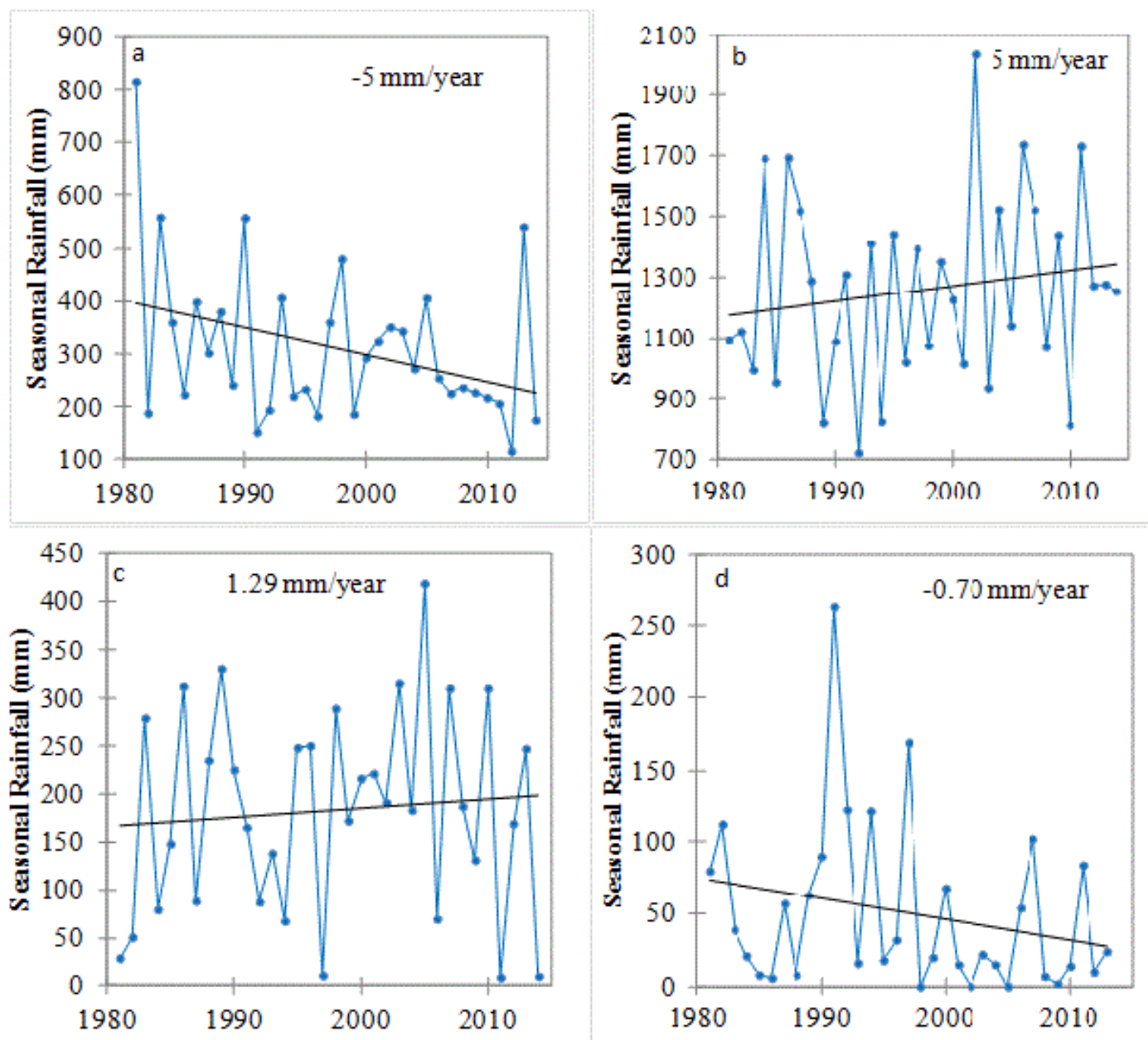

Figure 10: Seasonal Rainfall trend (a) pre-monsoon, (b) monsoon, (c) post-monsoon and (d) winter over Khulna district in recent climatic period (1981-2014). 

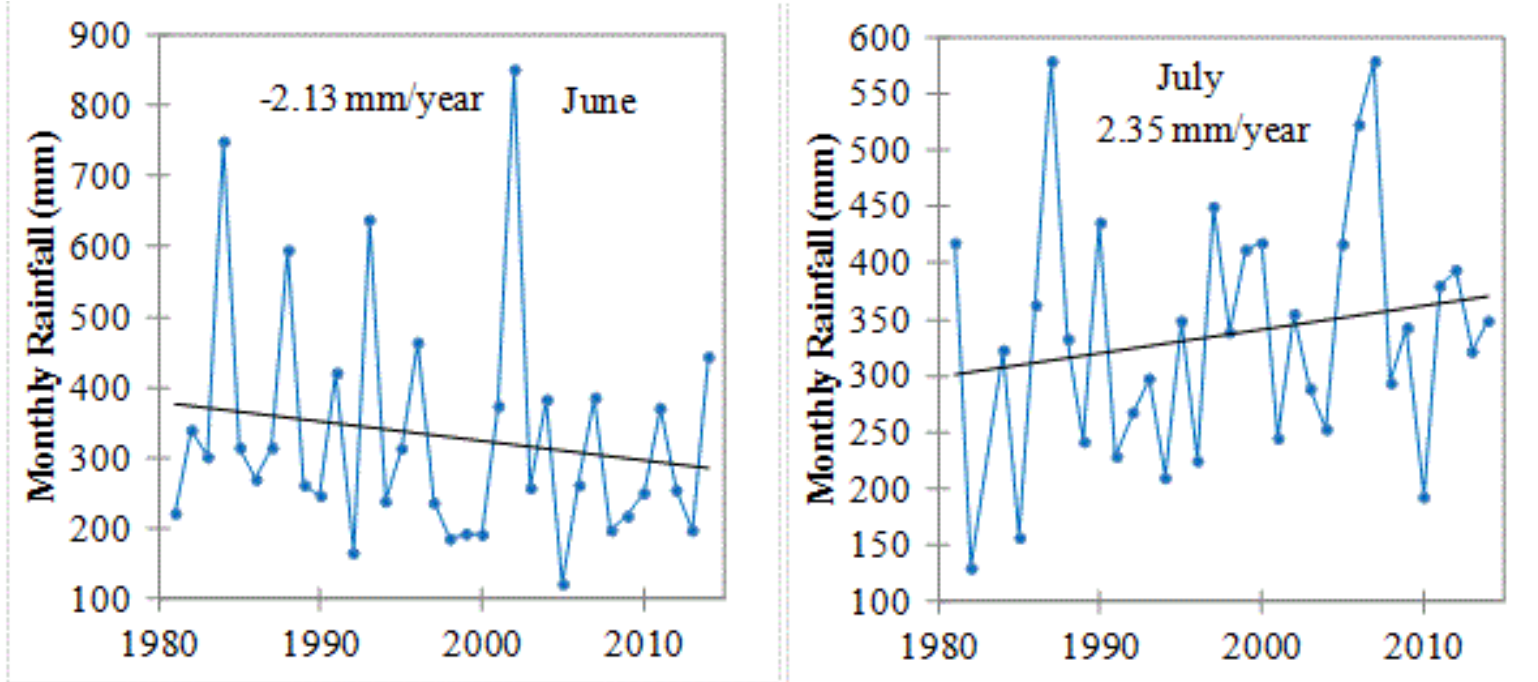

Figure 11: Monthly (June and July) rainfall trend over Khulna district in recent climatic period.

Local people of the study area also opined the observation of anomalous timing of monsoonal onset. Monthly rainfall trend (both Mann-Kendal and linear regression) over the month of June reveals a significant decreasing trend while overall monsoonal rainfall is increasing. Besides, rainfall trend over July is increasing, which represents a delayed onset of monsoon. In case of delayed monsoonal onset, transplantation of aman rice becomes delayed, and farmers have to incur yield loss. Delayed monsoon together with poor drainage and subsequent delayed water recession made loss of land for Boro cultivation. Post-monsoon rainfall also following a increasing trend (Figure 11). In addition to increased post-monsoonal rainfall, the area is under high risk of intense water logging condition.

\section{Impact of winter and Pre-monsoon Rainfall Anomaly}

Salinity intensification is a major problem in the study area. Salinity is increasing northward at a high rate. About 0.17 million hactares of new land has been affected by various degrees of soil salinity within 1973-2000 [17]. It is may be due to various reasons like fresh river water withdrawal from upstream, introduction of brackish water shrimp cultivation, faulty management of sluice gates, regular tidal water flooding in unpoldered area, capillary upward movement of soluble salts due to presence of high saline ground water table at shallower depth etc. According to the classification of SRDI the study area lies within slightly saline to highly saline group.

\section{Salinity Status of the Southwest Region}

Tidal flooding through a network of tidal creeks and drainage channels connected to the main river system inundates the soil and impregnates them with soluble salts thereby rendering both the top and subsoil saline. Saline water intrusion is highly seasonal. It is at its minimum during the monsoon (June-October) when the main rivers discharge about $80 \%$ of the annual fresh water flow. In dry season months, the saline front begins to penetrate inland, and affects the area with sharp rise from $10 \%$ in the monsoon to over $40 \%$. The salts enter the soil by flooding with saline river water or by seepage from the rivers, and the salts become concentrated in the surface layers through evaporation. The saline river water may also cause an increase in salinity of the ground water and make it unsuitable for irrigation. $70 \%$ of the 2.35 million hectares within the Khulna and Barisal Divisions is affected by different degree of soil salinity [1]. The decrease in water flow to the Gorai distributaries during the dry season has accentuated the surface water salinity in the southwest region. 1,98,890 ha of cultivable land in the coastal area is under moderately saline with strongly saline class developed by SRDI, where the soil of maximum land (37\%) contains high Electrical Conductivity (EC) value of 8.1-12.0 dS/m (Table 3). However $16 \%$ land under this class contains extreme EC value of $>16.0 \mathrm{dS} / \mathrm{m}$, those are highly detrimental for crop growth.

\section{Conclusion}

\section{According to the analysis the following conclusions can be drawn}

Amounts of annual rainfall in the southwestern part of Bangladesh are almost equal having very little spatial variation. Significant decreasing trend (Mann-Kendal) of annual rainfall over the region is found $(-4.5 \mathrm{~mm} /$ year at Mongla, $-9.14 \mathrm{~mm} /$ year at Jessore, $-15.71 \mathrm{~mm} /$ year at Madaripur) except Khulna, Satkhira and Khepupara, where the trend is positive over the long period (1948-2014) but it exhibits a decreasing trend during the recent period i.e., after 1980s. It clearly indicates a gradual decrease of the amount of rainfall over southwestern part, which has become most prominent in the recent climatic period of 1981-2014. The trend is more intense at the upper southwestern part, i.e., places like Jessore and Madaripur. Annual rainfall deviates within the range $-42.6 \%$ to $+48.6 \%$ over the region. Most wide annual deviation is observed in Khulna from $48.6 \%$ to $-35.5 \%$.

Like annual rainfall, seasonal rainfall also has anomalous behaviour over the region. Monsoon rainfall at maximum locations are syncline with annual trend, but at Khulna, Satkhira and Mongla though the annual trend is negative but the monsoon trend is positive, it clearly indicates, intensification of rainfall in monsoon period over the fore 
southwestern part. In pre-monsoon season, overall rainfall trend is significantly negative at maximum places $(-8.49 \mathrm{~mm} /$ year at Jessore, $-2.02 \mathrm{~mm} /$ year at Barisal, $-7.80 \mathrm{~mm} /$ year at Madaripur) over the region except Khulna, satkhira and Khepupara. But in Khulna and Satkhira it is also significantly negative over recent climatic period. Rainfall deviation is higher in seasonal scale than the annual scale. Among the seasons wider deviation is observed in winter (from $-100.0 \%$ to $+586 \%$ ) and narrower in monsoon (from $-43.0 \%$ to $+62.1 \%$ ).

The coastal region of southwest Bangladesh has been facing various natural extremes like salinity intensification, drainage congestion, inundation, water logging etc. Anomalous behavior of rainfall in combination with these problems, affecting agricultural crop production in the upazilas under study. The problem is serious in Rabi season, where groundwater irrigation facility is limited for salinity problem. In these areas agriculture is totally dependent on surface water (irrigation canal), which becomes scarce during the month of January, February, March and rainfall is also becoming low in this time (supports by public opinion and rainfall trend analysis) imposing water shortage in crop field and as a result farmers have to incur yield reduction. In monsoon season problem is different. Drainage congestion is a major problem in this time. A little heavy rainfall causes inundation and water logged condition. Besides this problem, increasing trend of rainfall in monsoon is very likely to intensify the risk of inundation. And the farmers of the study area have already faced total damage of Aus crop due to flooding in some years with comparatively high rainfall or fallow due to water logged condition.

Moreover, overall decreasing trend of rainfall is more likely to intensify the risks of salinization due to decreasing upstream flow as well as sedimentation on river bed and consequent poor drainage and water logging. This intensified environmental problem is further likely to intensify the detrimental effects on crop production.

So, changing pattern of rainfall in combination with the local environmental stress is being imposed on risk of agricultural crop production over the study area. It is also occasionally responsible for crop failure over the study area. It is also likely to further intensify the risk for future time.

\section{Salinity status of the southwest region}

Tidal flooding through a network of tidal creeks and drainage channels connected to the main river system inundates the soil and impregnates them with soluble salts thereby rendering both the top and subsoil saline. Saline water intrusion is highly seasonal. It is at its minimum during the monsoon (June-October) when the main rivers discharge about $80 \%$ of the annual fresh water flow. In dry season months, the saline front begins to penetrate inland, and affects the area with sharp rise from $10 \%$ in the monsoon to over $40 \%$. The salts enter the soil by flooding with saline river water or by seepage from the rivers, and the salts become concentrated in the surface layers through evaporation. The saline river water may also cause an increase in salinity of the ground water and make it unsuitable for irrigation. 70\% of the 2.35 million hectares within the Khulna and Barisal Divisions is affected by different degree of soil salinity [1]. The decrease in water flow to the Gorai distributaries during the dry season has accentuated the surface water salinity in the southwest region. $1,98,890$ ha of cultivable land in the coastal area is under moderately saline with strongly saline class developed by SRDI, where the soil of maximum land (37\%) contains high Electrical Conductivity (EC) value of 8.1-12.0 dS/m (Table 3). However $16 \%$ land under this class contains extreme EC value of $>16.0 \mathrm{dS} / \mathrm{m}$, those are highly detrimental for crop growth.

\section{References}

1. Haque SA (2009) Salinity Problems and Crop Production in Coastal Regions of Bangladesh. Pak J Bot 38: 1359-1365.

2. Intergovernmental Panel on Climate Change (2007) Climate Change 2007-The Physical science Basis; Fourth Assessment Report of the Intergovernmental Panel on Climate Change; Cambridge University Press: Cambridge, UK.

3. Government of Peoples Republic of Bangladesh (2005) Coastal Zone Policy, Monistry of Water Resources, Dhaka.

4. Rafiuddin M, Uyeda H, Islam MN (2010) Characteristics of monsoon precipitation systems in and around Bangladesh. Int J Climatol 30: 1042-1055.

5. Karim Z, Saheed SM, Salauddin ABM, Alam MK, Huq A (1982) Coastal saline soils and their management in Bangladesh. Soils Publication 8: 33.

6. Shahid S, Behrawan H (2008) Drought risk assessment in the western part of Bangladesh. H Nat Hazards 12: 36-42.

7. Ahmed AU (2004) Adaptation to climate change in Bangladesh: learning by doing. UNFCCC Workshop on Adaptation.

8. Ahmed A, Ryosuke S (2000) Climate change and agricultural food production of Bangladesh: an impact assessment using GIS-based biophysical crop simulation model. Center for Spatial Information Science.

9. Climate Change Cell, Who is doing What in Bangladesh? Report on the First Meeting (2006) Comprehensive Disaster Management Programme, Government of Bangladesh: Dhaka.

10. NIDOS (2009) Bangladesh Climate Change Factsheet, Network of International Development Organizations of Scotland.

11. The Center for Environmental and Geographic Information Services (CEGIS) (2011) Final Report on Activity 4: Programmes Containing Measures to Facilitate Adaptation to Climate Change of the Second National Communication Project of Bangladesh.

12. Rahman MR, Salehin M, Matsumoto J (1997) Trends of monsoon rainfall pattern in Bangladesh. Bangladesh J Water Resour 14: 121-138.

13. Rafiuddin M, Uyeda H, Islam MN (2007) Characteristics of Monsoon Precipitation Systems in Bangladesh during 2000-2005.

14. Roy K, Rahaman M (2009) Future Climate Change and Moisture Stress: Impact on Crop Agriculture in South-Western Bangladesh, Climate Change and Development Perspective 1: 1 .

15. Center of Excellence for Geospatial Information Science (2013) Vulnerability to Climate Induced Drought Scenario and Impacts, Comprehensive Disaster Management Programme (CDMP II).

16. Karim Z, Hussain SG, Ahmed M (1990) Salinity problems and crop intensification in the coastal regions of Bangladesh. Soils publication 33: 17.

17. Petersen L, Shireen S (2010) Soil and water salinity in the coastal area of Bangladesh. SRDI. 